Research, part of a Special Feature on Beyond Carbon: Enabling Justice and Equity in REDD+ Across Levels of Governance

\title{
Community Monitoring for REDD+: International Promises and Field Realities
}

\author{
$\underline{\text { Finn Danielsen }}^{1}, \underline{\text { Teis Adrian }}^{1}, \underline{\text { Søren Brofeldt }}^{2}$, Meine van Noordwijk $^{3}, \underline{\text { Michael K. Poulsen }}^{4}, \underline{\text { Subekti Rahayu }}^{3}, \underline{\text { Ervan }}$

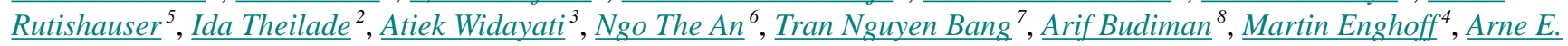 \\ Jensen $^{4}$, Yuyun Kurniawan $^{8}$, Qiaohong Li ${ }^{9}$, Zhao Mingxu ${ }^{9}$, Dietrich Schmidt-Vogt ${ }^{9}$, Suoksompong Prixa ${ }^{10}$, Vongvisouk

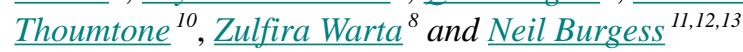

\begin{abstract}
Will community monitoring assist in delivering just and equitable REDD+? We assessed whether local communities can effectively estimate carbon stocks in some of the world's most carbon rich forests, using simple field protocols, and we reviewed whether community monitoring exists in current REDD+ pilots. We obtained similar results for forest carbon when measured by communities and professional foresters in 289 vegetation plots in Southeast Asia. Most REDD+ monitoring schemes, however, contain no community involvement. To close the gulf between United Nations Framework Convention on Climate Change texts on involving communities and field implementation realities, we propose greater embedding of community monitoring within national REDD+ pilot schemes, which we argue will lead to a more just REDD+.
\end{abstract}

Key Words: biodiversity; Climate, Community and Biodiversity Alliance standard; forest carbon; governance; livelihood; monitoring; Payment for Ecosystem Service programs; REDD+; Southeast Asia

\section{INTRODUCTION}

Efforts to reduce greenhouse gas emissions from deforestation and forest degradation (core elements of Reduced Emissions from Deforestation and Degradation [REDD+]) require the convergence of (1) international rules, finance, and investment; (2) national accountability for future emission levels compared with current ones; and (3) local changes in incentives and behavior that involve the major external and local drivers of change in tropical forest margins (Ghazoul et al. 2010, Angelsen et al. 2011).

Current United Nations Framework Convention on Climate Change (UNFCCC) texts and guidance documents on the technical aspects of REDD+ outline explicit roles for indigenous people and local communities in implementing REDD+ (GOFC-GOLD 2010, Epple et al. 2011, UNFCCC $2011 a, b$ ), and state that projects should secure Free Prior and Informed Consent before implementation begins (UN-REDD 2011, FPP 2012). However, it has been questioned whether these good intentions are being translated into activities on the ground in countries where pilot projects are testing modalities for implementing REDD+ (Angelsen et al. 2009, Howell 2012).

In recent years, a broad literature has been generated on the many methods that can be employed to measure forest carbon at the scale of the nation state or subregional areas within a nation (e.g., Asner et al. 2010, GOFC-GOLD 2010). Typically, these involve a combination of remote sensing (with many options available) and plot-based carbon measurements carried out by professional foresters (with many ways of doing this work), in combination with data on wood density, and various conversion factors to convert tree measurements in the field to biomass carbon. Less often, these procedures also include other Intergovernmental Panel on Climate Change (IPCC) carbon pools (deadwood, roots, soil carbon), and considerations of REDD+ safeguards, such as biodiversity and local livelihoods. The available literature relates mainly to the national monitoring, reporting, and verification processes. At field REDD+ pilot project scale, the range of approaches being tested is smaller but expanding, and is beginning to include more participatory and communitybased approaches to monitoring because these may have greater resonance at the local level (Skutsch 2011, Mukama et al. 2012).

Despite the many scientific papers now being published on REDD+, the different ways it might be implemented, and the various consequences, good or bad, on forests, people, and biodiversity (Robledo et al. 2008, Chhatre and Agrawal 2009, Putz and Redford 2009, Venter et al. 2009, Ghazoul et al. 2010, Rights and Resources 2010, Fisher et al. 2011, Gardner et al. 2012, Strassburg et al. 2012), many of the papers remain primarily theoretical. This is partly because REDD+ projects are mainly readiness and pilot activities that have been started only in the past few years, and there has not been enough time to collect quantitative data and analyze relevant

\footnotetext{
${ }^{1}$ Nordisk Fond for Miljø og Udvikling, Copenhagen, ${ }^{2}$ Forest and Landscape of Denmark, University of Copenhagen, ${ }^{3}$ World Agroforestry Centre, ${ }^{4}$ NORDECO, ${ }^{5}$ Center for International Forestry Research, ${ }^{6}$ Hanoi University of Agriculture, ${ }^{7}$ Department of Environmental Management, Faculty of Natural Resources and Environment, Hanoi University of Agriculture, ${ }^{8}$ WWF-Indonesia, ${ }^{9}$ Kunming Institute of Botany, Chinese Academy of Sciences, ${ }^{10}$ National University of Laos, ${ }^{11}$ Centre for Macroecology, Evolution and Climate, Department of Biology, University of Copenhagen, ${ }^{12}$ WWF-US Conservation Science Program, ${ }^{13}$ UNEP-World Conservation Monitoring Center, Cambridge
} 
implementation lessons. Other papers have used REDD+ to reopen older debates on forest conservation and management through the new optic of carbon forestry.

Little has been published on existing efforts to involve local stakeholders in REDD+ implementation or on how community-based REDD+ should be undertaken in practice, including issues of community-level monitoring of carbon, livelihoods, or biodiversity. Past work does, however, suggest that community involvement in monitoring enhances feelings of ownership and improves governance while building local capacity (Andrianandrasana et al. 2005, Danielsen et al. 2005, Gibson et al. 2005). Moreover, local people's participation in monitoring has been shown to enhance decision-making at the operational level of forest management (Danielsen et al. 2007, 2010). Monitoring forest carbon, biodiversity, and livelihoods by local communities may, therefore, be one part of the foundations of a fair and equitable REDD+.

Previous studies have shown that communities can monitor biomass in relatively simple-structured forests, for example Tanzanian miombo (Brachystegia) woodland and temperate montane Himalayan oak (Quercus) and pine (Pinus) forests (Skutsch et al. 2011). However, not a single study yet reports data on the ability of local communities to monitor aboveground biomass (AGB) in the complex old-growth tropical forests of South America, Africa, or Southeast Asia, where the large number of species and difficulties of access make surveys much more challenging (Dam and Trines 2011).

Previous local monitoring protocols have also relied mainly on the use of handheld computers (Peters-Guarin and McCall 2011), which may represent a constraint to community involvement and the broad-scale implementation of the approach because capacity is limited in some communities (Howell 2012). Employing low-tech field approaches, such as recording of data using pen and paper, measuring using ropes marked at relevant points, and utilizing other feasible protocols for local communities, may greatly enhance the application of the approach.

Current conservation practice provides examples of how community monitoring of REDD+ might be able to develop. For example, the community forest conservation approach started in Nepal through policy changes in the 1960s and pilot projects in the 1970s (Acharya 2002, Kanel 2004), which have expanded to a national program covering more than 1.65 million ha of woodland and 2.18 million households (Anon. $2012 a, b$ ), and has been widely replicated around the world (Carter and Gronow 2005). Community monitoring of Tanzanian miombo and Himalayan oak forest both started as components of a donor funded research and capacity-building program (Skutsch 2011), and could therefore be regarded as isolated examples that could be driven by the researchers' funding rather than genuine community involvement. Alternatively, these approaches and their results may represent the beginnings of a broader movement, like community forestry in Nepal, that could self-replicate around the world and become a major element in reducing forest degradation and deforestation.

The other main considerations in the implementation of REDD+ in the field are political and can be framed in terms of power relations. The negotiations between the local, national, and international stakeholders in REDD+ mechanisms require a "level playing field" in terms of understanding and appreciating the quantitative aspects of emissions and emissions reduction. Clark et al. (2011) introduced the Salience, Credibility and Legitimacy Framework into the discussions of natural resource management. Knowledge products require all three attributes before they will be noticed and accepted as the basis for negotiations. Salience refers to the opportunity to relate results to policies and actions, credibility to the use of correct method and procedure, and legitimacy to the appropriate involvement of stakeholders. The discussion of community involvement in REDD+ may benefit from analysis along these lines.

We broadly address three issues related to the involvement of indigenous people and local communities in the implementation of REDD+ on the ground. First, we assess the ability of local communities to accurately estimate AGB in several forests across Southeast Asia using a simple-to-use methodology within national REDD+ programs. Second, we review current efforts to involve local communities in monitoring carbon, biodiversity, and livelihoods within forest carbon projects that are accredited by the Climate, Community and Biodiversity Alliance (CCBA) around the world. Third, we assess and discuss the application of community monitoring in REDD+ schemes and its implementation in the field, with emphasis on community forest management.

The specific questions we address are as follows:

1. How well can communities measure AGB in Southeast Asian forests?

2. To what extent has community monitoring been taken up in existing REDD+ programs?

3. How does the current situation on the ground link with the "intention" of the current UNFCCC texts on carbon monitoring and safeguards for the proposed REDD+ mechanism?

4. How will community monitoring of REDD+ projects become operational "at scale", beyond limited application in current pilots and research projects?

5. Does the involvement of communities in monitoring of forest carbon and REDD+ safeguards improve the chance of equitable and just implementation of this primarily climate change mitigation tool? 


\section{METHODS}

\section{Measurement of forest carbon}

\section{Study sites and data collectors}

We collected new data from permanent vegetation plots in nine forest types of Indonesia, China, Laos, and Vietnam. Study sites were opportunistically chosen in the four countries. Among the selection criteria were the usage by local communities of the candidate forest sites and the potential for reduction of forest degradation.

In Central Kalimantan, Indonesia, plots were established in Batu Majang village, Kutai Barat District, in the Province of East Kalimantan, in lowland dipterocarp forest $(40-500$ meters above sea level [m.a.s.l.]; 400 ha). On forest margins, a few large trees were harvested by the local community, but most of this forest has remained unmanaged over the last decades (Rutishauser et al., in press).

The study area in China was in Man Lin village in Xiangming township of Xishuangbanna Autonomous Prefecture, Yunnan Province. It comprises tropical mountain forest at 900-1200 m.a.s.l. In total, 761 ha in two forest types were surveyed: slightly disturbed forest (470 ha) and moderately disturbed forest (291 ha), including overgrown swidden fields and areas with ancient tea trees mixed with natural forest vegetation.

In Laos, the study area was in Ban Sakok village, Viengthong District, Hauphan Province, and was in hilly evergreen monsoon forest between 600 and 1600 m.a.s.l. In total, 162 ha in two forest types (100 ha and 62 ha) were surveyed: primary closed forest and disturbed open forest surrounded by old and new swidden fields.

In Vietnam, the study areas were in Diem and Moi villages in Con Cuong District, Nghe An Province, within lowland evergreen monsoon forest between 160 and 460 m.a.s.l. In total, 314 ha in four forest types (125 ha, 104 ha, $67 \mathrm{ha}$, and $18 \mathrm{ha}$ ) were surveyed. The degree of disturbance varied from almost undisturbed forest to secondary forest, severely degraded forest, and forest regrowth in former swidden fields (Appendix 1).

Plots were measured by both community members and professional foresters between September 2011 and May 2012. Representatives of the local communities helped select community participants for the monitoring based on their interest and experience with forest resources; hence, these community members were probably more skilled than the average villager. All community monitors had attended primary school, and all received 1-2 days training in methods and approaches from intermediate organizations (research organizations and nongovernmental organizations [NGOs]). In addition, the intermediate organizations supervised the community monitors in mapping forest areas and locating plots with GPS devices for 3-5 days in each study area. The professional monitors all had academic degrees within natural science, and they had on average four years of work experience with forest assessments in practice.

All communities were in rural areas. The community in Kalimantan was connected to other communities only by river and relied mainly on subsistence agriculture, while the villages in China, Laos, and Vietnam were connected by road. Villagers in Laos and Vietnam sold part of their agricultural produce at markets, whereas villagers in China were involved in growing rubber in plantations and were relatively wealthier.

The different forest types monitored encompassed a wide range of land tenure and usufruct rights, i.e., communal forest (Indonesia), collective forest (China), State forest (China), and State forest with user rights allocated to villagers (Laos and Vietnam).

\section{Methods for measurements of forest carbon}

To measure forest biomass, we used a simplified version of the radial nested sampling methods described by Verplanke and Zahabu (2009) and Hairah et al. (2011a) (Appendix 2). Community members first identified total forest area on printed maps with the assistance of an intermediate organization (IO). Based on available knowledge of forest history (i.e., previous logging or swidden agriculture), the community members and the staff of the IO stratified the forest into homogenous strata (referred to as "forest type"), and these were treated as independent entities in the monitoring.

In each stratum, the community members and the staff of the IO established 15 randomly selected pilot plots so that the staff of the IO could determine the biomass stock variability and estimate the number of plots required to assess the biomass stock of the stratum with a coefficient of variation (C.V.) < 20\% (Wagner et al. 2010).

Based on this pre-analysis, staff of the IO randomly chose the number and location of plots that were needed across the stratum and indicated these on a map. After this, community members on their own but supervised by one IO staff, and professional foresters independently carried out forest inventories in each plot with a maximum of four months in between.

All trees with girth $\geq 30 \mathrm{~cm}$ (as a proxy for diameter at breast height $[\mathrm{DBH}] \geq 10 \mathrm{~cm})$ and with girth $\geq 100 \mathrm{~cm}(\mathrm{DBH} \geq 30$ $\mathrm{cm}$ ) had their girth measured at $130 \mathrm{~cm}$ from tree base within a radius of $9 \mathrm{~m}$ and $15 \mathrm{~m}$ from plot center, respectively. In Vietnam and Laos, each measured tree was furthermore numbered to allow a tree-to-tree comparison of girth measurement between observers. IOs entered the data into Excel and estimated the total tree AGB using Brown's generic equation (Brown 1997). This practice is in line with the methodology recommended by the IPCC Good Practice Guidance (Penman et al. 2003). 
Costs of community-based and professionally executed measurements were estimated on the basis of the actual expenses incurred for local transport and during the training and fieldwork.

We analyzed whether community members and professional foresters measured the same number of trees per plot, measured the same girth per tree, and recorded the same biomass per hectare estimated per plot. For the analysis of tree girth and number of trees per plot, we used Wilcoxon signed rank tests and a significance level of 0.05 . The comparison of tree girths was possible only in Laos and Vietnam because the trees were marked individually in those countries. For comparing the biomass per hectare, we first square root transformed the data so they would fit a Gaussian distribution. We thereafter tested community data and forester data individually for outliers by identifying values that exceeded $3 x$ standard deviations. If the outlying value of one data set did not parallel an outlying value of the other at the same plot, we excluded the corresponding plot because it was clearly identifiable as a miscalculated value. We then compared the mean biomass by a match-paired Student's $t$ test and compared the variance by an $F$ test.

Furthermore, to test whether the numbering of individual trees had an effect on the number of trees measured between community-based and professionally executed methods, we compared Vietnam and Laos to the rest of the countries regarding the proportion of plots with exactly the same number of measured trees using a $\chi^{2}$ test (with software from Preacher 2001).

Finally, to explore the relationship between the number of community member and forester plots needed in a forest stratum and the biomass C.V., we applied a bootstrap procedure along which $n$ plots were randomly selected 1000 times. From this distribution, we computed the biomass C.V. for both the community members and the professional foresters.

\section{Assessment of uptake of community monitoring within existing REDD+ programs}

To assess the extent to which community monitoring has been taken up in existing forest carbon programs, we located the project design documents for all projects that have been validated by the CCBA Standard (http://www.climatestandards.org/ccb-standards/), which is one of the most widely used forest certification standards (Merger et al. 2011).

The CCBA Standards apply to land-based carbon projects that (1) "reduce greenhouse gas emissions through avoided deforestation and forest degradation (REDD)" and (2) "remove carbon dioxide by sequestering carbon (e.g., reforestation, afforestation, re-vegetation, forest restoration, agroforestry and sustainable agriculture)"(CCBA 2008, p. 7).
We used five categories to determine the degree of local stakeholder involvement in the monitoring, broadly following the monitoring typology established by Danielsen et al. (2009). These categories are easy to extract objectively from the CCBA project design documents and are clearly separate from each other:

1. There is no involvement of local stakeholders in monitoring.

2. Local stakeholders assist in, or conduct parts of monitoring, but professional foresters are actively involved in on-the-ground monitoring activities.

3. Local stakeholders conduct all on-the-ground monitoring themselves, but reporting and analysis are done by professional foresters.

4. Local stakeholders conduct all on-the-ground monitoring and report the data to a central unit independently and/or actively participate in the design and implementation phase of the monitoring scheme. Professional foresters conduct the analysis of the monitoring data.

5. Local stakeholders participate in the design and implementation phase of the monitoring scheme, conduct all on-the-ground monitoring, and report and analyze all on-the-ground data themselves.

For all CCBA monitoring schemes, an independent verification of the monitoring process and data from a third party are required; thus, we see verification as an autonomous program that does not influence the degree of participation by local stakeholders in monitoring. For the purpose of an analysis of uptake of community monitoring within existing REDD+ programs, we defined local stakeholders as local resource users or local government staff.

We used Pearson's $\chi^{2}$ test (with software from Preacher 2001) to compare the degree of local stakeholder involvement between CCBA-validated project types (REDD+ vs. no REDD+; Forest Enhancement vs. Reduced Forest Degradation), and between the continents. To investigate if projects involving local stakeholders in one type of monitoring were also more likely to involve them in others, we conducted a Simpson's similarity measure between carbon, biodiversity, and livelihood monitoring (Koleff et al. 2003). We compared the observed Simpson's similarity against 1000 randomizations of monitoring schemes (or bootstrapping) and tested whether they were higher than expected if there was no linkage between types.

\section{Linking reality on the ground to United Nations Framework Convention on Climate Change texts}

We reviewed the text of the current proposed REDD+ mechanism (decision 1/CP.16) and the proposed text for the biodiversity and livelihoods safeguards (decision 1/CP.16, its 
Table 1. Measurements of aboveground biomass (AGB) by local community members and professional foresters in four Southeast Asian countries, with $p$ values for total biomass estimates (matched pair $t$ test) and variance ( $F$ test), tree girth measurement (Wilcoxon signed rank test), and plot demarcation (Wilcoxon signed rank test) ( $n=289$ permanent plots). Significant values are shown in bold (n.a. = not available).

\begin{tabular}{|c|c|c|c|c|c|c|c|c|}
\hline Country & $\begin{array}{l}\text { Name of area } \\
\text { (site number) }\end{array}$ & $\begin{array}{l}\text { Number } \\
\text { of plots }\end{array}$ & $\begin{array}{c}\text { Community } \\
\text { survey of biomass } \\
\text { (Mean AGB in } \\
\mathrm{Mg} \cdot \text { ha-1) }\end{array}$ & $\begin{array}{l}\text { Forester survey } \\
\text { of biomass } \\
\text { (Mean AGB in } \\
\mathrm{Mg} \cdot \text { ha-1) }\end{array}$ & $\begin{array}{c}\text { Biomass estimates } \\
\text { (square root } \\
\text { transformed) } \\
p\end{array}$ & $\begin{array}{l}\text { Variance of } \\
\text { biomass } \\
\text { estimates } \\
\text { (square root } \\
\text { transformed) } \\
p\end{array}$ & $\begin{array}{c}\text { Tree girth } \\
(\mathrm{cm}) \\
p^{\dagger}\end{array}$ & $\begin{array}{c}\text { Plot demarcation } \\
\text { (Tree inclusion and } \\
\text { exclusion) } \\
p \dagger\end{array}$ \\
\hline Indonesia & $\begin{array}{l}\text { Batu Majang } \\
\text { (a) }\end{array}$ & 64 & $381 \div$ & $449 \neq$ & $<0.01 †$ & $0.048 \ddagger$ & n.a. $\S$ & $<0.01(20 \%)$ \\
\hline China & Manlin (b) & 30 & 332 & 303 & $<0.01$ & 0.51 & n.a. & $0.26(23 \%)$ \\
\hline China & Manlin (c) & 30 & 235 & 219 & 0.32 & 0.34 & n.a. & $0.15(0 \%)$ \\
\hline Laos & Sakok (d) & 32 & 293 & 301 & 0.21 & 0.57 & $<0.01(38 \%)$ & n.a.| $(97 \%)$ \\
\hline Laos & Sakok (e) & 30 & 204 & 208 & 0.02 & 0.41 & $<0.01(53 \%)$ & n.a.| $(88 \%)$ \\
\hline Vietnam & $\operatorname{Diem}(f)$ & 30 & 106 & 104 & 0.34 & 0.34 & $0.60(47 \%)$ & $0.02(60 \%)$ \\
\hline Vietnam & Moi (g) & 18 & 105 & 105 & 0.56 & 0.63 & $0.051(54 \%)$ & $0.67(22 \%)$ \\
\hline Vietnam & Moi (h) & 28 & 89.0 & 88.9 & 0.94 & 0.46 & $0.38(53 \%)$ & $0.05(50 \%)$ \\
\hline Vietnam & Moi (i) & 27 & $50.7 \ddagger$ & $52.3 \ddagger$ & $0.20 \ddagger$ & $0.41 \ddagger$ & $0.02(47 \%)$ & $0.38(56 \%)$ \\
\hline \multicolumn{9}{|c|}{$\begin{array}{l}\dagger \text { In brackets, the proportion of measured trees (tree girth) and plots (plot demarcation) where community members’ and foresters’ measurements } \mathrm{h} \\
\text { perfect match. } \\
\text { \$One plot was excluded because it violated } 3 \mathrm{x} \text { standard deviation of the mean. (For Batu Majang, Indonesia, } n=63 ; \text { for Moi [i], Vietnam, } n=26 \text { ) } \\
\text { \$ Data are not available because trees were not individually marked. } \\
\text { No } p \text { value is available because too few degrees of freedom exist for Wilcoxon's signed rank test. }\end{array}$} \\
\hline
\end{tabular}

Appendix 1) to determine the degree to which community monitoring and the involvement of local people was mentioned in the official documents in comparison to the field realities in countries with CCBA-accredited projects. We also searched the various UN-REDD guidance documents for information on how safeguards are addressed and respected (UNFCCC/SBSTA/2011/L.25/Add.1) and the draft decision of the Ad Hoc Working Group on Long-term Cooperative Action under the Convention (AWG-LCA Draft decision [-/ CP.17] 2011).

\section{RESULTS}

\section{How well can communities measure carbon in Southeast Asian forests?}

\section{Biomass}

With a square root transformation of biomass estimates, all sites showed a clear normal distribution (Shapiro-Wilk $p>$ 0.05 , compared with visual identification). Two plots were excluded due to violations of $3 \mathrm{x}$ standard deviation (s.d.): one in Batu Majang, Indonesia (3.87x s.d.) and one in site (i) in Moi, Vietnam (4.23x s.d.). Both were due to outlying values among community measurements.

Overall, the aboveground biomass estimated by community members differed only slightly from the estimates of professional foresters (Fig. 1, Fig. 2, Table 1). However, the difference was significant in one-third of the sites (three sites out of nine) ( $t$ test, $p<0.05$; Table 1$)$.
To explore the precision of measurements by community members and professional foresters, we compared the variance of biomass estimates and found that there was significant difference at only one site out of nine ( $F$ test, $p<0.05$; Table $1)$. Moreover, we examined the relationship between the number of plots needed in a forest stratum and the biomass $C$. V. (Fig. 3). In Batu Majang, Indonesia, to obtain the same precision as foresters, the community members would need to sample twice the number of plots-i.e., to achieve a C.V. of $15 \%$, community members would need about 30 plots, while foresters would require only 15 plots (Fig. 3a). Likewise, in Moi (Vietnam), to obtain a C.V. of $15 \%$, the community members would need about 20 plots but foresters would need only 15 plots (Fig. 3g). In contrast, in Manlin (China), Sakok (Laos), and Diem (Vietnam), the local community members had approximately the same precision as the foresters (Fig. $3 \mathrm{~b}, \mathrm{c}, \mathrm{d}, \mathrm{e}$, and f).

\section{Tree girth}

In Laos and Vietnam, trees were numbered by the community members and remeasured by professional foresters. At these sites, we investigated the difference in girth measurement among both types of observers. At three out of six sites, two in Laos and one in Vietnam, there were significant differences between community monitors and foresters, but a high proportion of the trees was measured exactly the same at the measuring tape's resolution of one centimeter (Table 1). 
Fig. 1. Relationship between the aboveground woody biomass recorded by community members and forester plot-based aboveground biomass measurement in lowland dipterocarp forest in Batu Majang, Indonesia (a), mountain rain forest in Manlin, China (b-c), evergreen monsoon forest in Sakok, Laos (d-e), and Diem (f) and Moi (g-i), Vietnam (with same units on $\mathrm{y}$-axes as on $\mathrm{x}$-axes and $\mathrm{y}=\mathrm{x}$ lines; $n=289$ permanent plots). Each point in the graphs represents one census of aboveground woody biomass in a permanent plot by community members (y-axes) and foresters (x-axes).

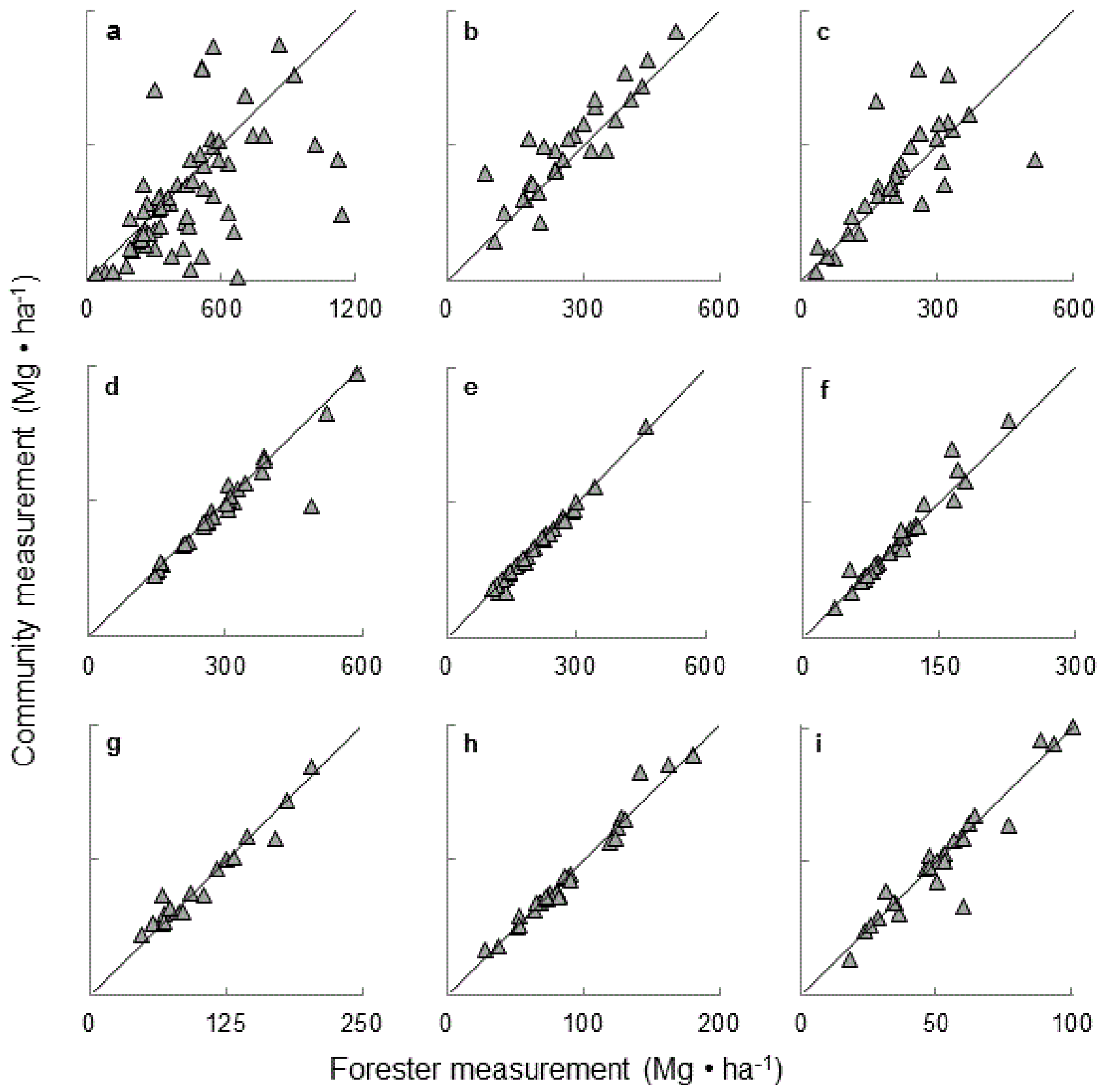


Fig. 2. Comparison of woody biomass data in diverse Southeast Asian forests compiled by community members and professional foresters. Measurements of aboveground woody biomass were made by community members $(\mathrm{C})$ and foresters $(F)$ over a range of lowland dipterocarp forest in Batu Majang, Indonesia (a), mountain rainforest in Manlin, China (b-c), evergreen monsoon forest in Sakok, Laos (de), and Diem (f) and Moi (g-i), Vietnam ( $n=289$ permanent plots; $\log 10$ scale). The different points in each column show the smallest observation, lower quartile, median, upper quartile, and largest observation.

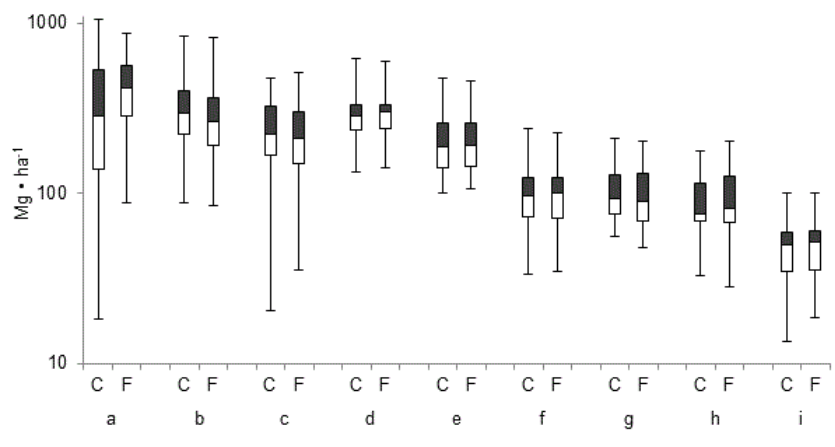

Further analysis revealed that the distribution of differences in girth measurements was slightly skewed (Appendix 5). Villagers consistently measured slightly lower girths than foresters. However, we found high kurtosis values of the distribution modes, indicating high agreement between the community members and the professional foresters for most girth measurements (Appendix 5).

\section{Plot demarcation}

The analysis of the plot demarcation efforts of the community monitors (the inclusion or omission of trees in plots) showed that in both countries where trees were numbered individually, i.e., Vietnam and Laos, there was a much higher percentage of plots where community monitors and foresters found exactly the same number of trees $\left(\chi^{2}\right.$ test, $\left.p<0.01\right)$.

\section{Costs}

We estimated the costs of monitoring forest biomass by community members and by foresters on a per plot basis. We found that, from an external perspective, the community measurements of aboveground biomass in the first year cost US\$39-\$82 per plot, whereas forester-executed biomass measurements cost US\$22-\$53 per plot (Table 2, Appendix 3). Community measurements required more funds for training but there were higher expenditures for travel, accommodation, and salaries for professional forester measurements (Table 2).
To what extent has community monitoring been taken up by existing REDD+ pilot projects?

To date (April 13, 2012), 50 forest carbon projects have been validated by the CCBA. From the project design documents, we were able to retrieve information on 50 biomass/carbon, 47 biodiversity, and 48 livelihood monitoring schemes (data set in Appendix 7).

Our analysis showed that $48 \%$ (24) of the CCBA-validated projects had no planned involvement of local stakeholders in monitoring, as illustrated in Fig. 4. At the other end of the spectrum, $12 \%$ (6) of the CCBA-validated projects involved local stakeholders in monitoring biomass, biodiversity, and livelihoods (Appendix 7).

We found that CCBA projects involving local stakeholders in monitoring biomass often also involved local stakeholders in monitoring biodiversity $\left(S_{S i m}=0.92\right)$, whereas we found no correspondence between schemes that involved local stakeholders in monitoring livelihoods and schemes that involved locals in monitoring biomass or biodiversity (livelihood and carbon $\mathrm{S}_{\mathrm{Sim}}=0.5$; livelihood and biodiversity $\mathrm{S}_{\text {Sim }}=0.57$ ).

The involvement of local stakeholders in CCBA monitoring varied across the continents (Appendix 6). Community carbon monitoring showed a pattern towards being widespread in Africa ( $p=0.12, n=13)$ and less common in North America ( $p=0.12, n=9)$. Likewise, community biodiversity monitoring was significantly more common in Africa $(p=$ $0.03)$ and less common in North America $(p=0.03)$.

The involvement of local stakeholders in CCBA monitoring also varied across time. Between July 2009 and April 2012, CCBA projects increasingly involved local stakeholders in monitoring of biodiversity, biomass, and livelihoods (Fig. 5). Finally, local involvement in CCBA project monitoring was more frequent in "reduced forest degradation" schemes than in "forest enhancement" schemes (Table 3).

\section{Is field practice in line with the "intention" of the REDD+ and safeguards texts?}

The UNFCCC calls for the development of a "system for providing information on how safeguards are being addressed and respected through the implementation of [REDD+] activities" (UNFCCC Decision 1/CP.16 p71d). Likewise, the UNFCCC specifically calls for "ensuring the full and effective participation of relevant stakeholders, inter alia, indigenous peoples and local communities" (UNFCCC Decision 1/CP.16 p72). The last quote refers to participation in general and not directly to monitoring activities. Appendix 1 of the REDD+ text specifies that activities should promote and support "Respect for the knowledge and rights of indigenous peoples and members of local communities, by taking into account relevant international obligations, national circumstances and laws," and reiterates "the full and effective participation of 
Table 2. Cost of community and professional forester-executed measurements of biomass in the study areas in Indonesia, China, Laos, and Vietnam (details in Appendix 3). All costs are in US\$.

\begin{tabular}{|c|c|c|c|c|c|c|c|c|c|c|c|c|}
\hline Country & $\begin{array}{c}\text { Name of } \\
\text { area (site } \\
\text { number) }\end{array}$ & $\begin{array}{c}\text { No. of } \\
\text { plots }\end{array}$ & $\begin{array}{c}\text { Data } \\
\text { gatherer }\end{array}$ & $\begin{array}{c}\text { Training } \\
\text { and } \\
\text { supervi- } \\
\text { sion } \dagger\end{array}$ & $\begin{array}{l}\text { Travel } \\
\text { and } \\
\text { accommo- } \\
\text { dation for } \\
\text { data } \\
\text { gatherer }\end{array}$ & $\begin{array}{c}\text { Food for } \\
\text { data } \\
\text { gatherer }\end{array}$ & Equipment & Wages & $\begin{array}{c}\text { Total cost } \\
\text { year } 1\end{array}$ & $\begin{array}{c}\text { Estimated } \\
\text { total cost } \\
\text { year } 1-4\end{array}$ & $\begin{array}{c}\text { Total cost } \\
\text { per plot } \\
\text { year } 1\end{array}$ & $\begin{array}{c}\text { Estimated } \\
\text { total cost } \\
\text { per plot per } \\
\text { year } 1-4\end{array}$ \\
\hline Indonesia & $\begin{array}{c}\text { Batu } \\
\text { Majang (a) }\end{array}$ & 64 & $\begin{array}{c}\text { Commu- } \\
\text { nity }\end{array}$ & 2212 & 0 & 146 & 48 & 435 & 2841 & 6392 & 44 & 25 \\
\hline Indonesia & $\begin{array}{c}\text { Batu } \\
\text { Majang (a) }\end{array}$ & 64 & $\begin{array}{l}\text { Professi- } \\
\text { onal }\end{array}$ & 0 & 385 & 353 & 15 & 1887 & 2640 & 7332 & 41 & 29 \\
\hline China & $\begin{array}{c}\text { Manlin } \\
(\mathrm{b}-\mathrm{c})\end{array}$ & 60 & $\begin{array}{c}\text { Commu- } \\
\text { nity }\end{array}$ & 2218 & 0 & 0 & 20 & 384 & 2622 & 5634 & 44 & 23 \\
\hline China & $\begin{array}{c}\text { Manlin } \\
(\mathrm{b}-\mathrm{c})\end{array}$ & 60 & $\begin{array}{c}\text { Professi- } \\
\text { onal }\end{array}$ & 0 & 416 & 48 & 0 & 836 & 1300 & 5200 & 22 & 22 \\
\hline Laos & Sakok (d-e) & 62 & $\begin{array}{c}\text { Commu- } \\
\text { nity }\end{array}$ & 2944 & 0 & 0 & 211 & 526 & 3681 & 11177 & 59 & 45 \\
\hline Laos & Sakok (d-e) & 62 & $\begin{array}{c}\text { Professi- } \\
\text { onal }\end{array}$ & 0 & 2263 & 0 & 288 & 750 & 3301 & 11376 & 53 & 46 \\
\hline Vietnam & $\begin{array}{l}\text { Diem } \\
\text { (f) }\end{array}$ & 30 & $\begin{array}{c}\text { Commu- } \\
\text { nity }\end{array}$ & 2198 & 0 & 58 & 95 & 100 & 2451 & 5153 & 82 & 43 \\
\hline Vietnam & $\begin{array}{l}\text { Diem } \\
\text { (f) }\end{array}$ & 30 & $\begin{array}{c}\text { Professi- } \\
\text { onal }\end{array}$ & 0 & 475 & 554 & 11 & 255 & 1295 & 5180 & 43 & 43 \\
\hline Vietnam & $\begin{array}{l}\text { Moi } \\
(\mathrm{g}-\mathrm{i})\end{array}$ & 73 & $\begin{array}{l}\text { Commu- } \\
\text { nity }\end{array}$ & 2098 & 0 & 255 & 181 & 343 & 2877 & 8897 & 39 & 30 \\
\hline Vietnam & $\begin{array}{l}\text { Moi } \\
(\mathrm{g}-\mathrm{i})\end{array}$ & 73 & $\begin{array}{l}\text { Professi- } \\
\text { onal }\end{array}$ & 0 & 950 & 1152 & 11 & 510 & 2623 & 10492 & 36 & 36 \\
\hline
\end{tabular}

$\dagger$ Including travel, accommodation, food and wages for trainers

Table 3. Proportion of Reduced Forest Degradation and Forest Enhancement forest carbon projects validated by the Climate, Community and Biodiversity Alliance (up to April 13, 2012) that involve local stakeholders in monitoring carbon, biodiversity, and livelihoods.

\begin{tabular}{llll}
\hline \hline & Carbon & Biodiversity & Livelihood \\
\hline $\begin{array}{l}\text { Reduced Forest Degradation } \\
\text { projects } \\
(n=17)\end{array}$ & $\begin{array}{l}47 \% \\
(n=17)\end{array}$ & $\begin{array}{l}53 \% \\
(n=17)\end{array}$ & $\begin{array}{l}25 \% \\
(n=17)\end{array}$ \\
$\begin{array}{l}\text { Forest Enhancement } \\
\text { projects } \\
(n=33)\end{array}$ & $15 \%$ & $27 \%$ & $31 \%$ \\
Pearson's $\chi^{2} \dagger$ & $(n=33)$ & $(n=30)$ & $(n=32)$ \\
\hline
\end{tabular}

$\dagger$ Between Reduced Forest Degradation projects and Forest Enhancement projects

relevant stakeholders, in particular, indigenous peoples and local communities" (UNFCCC Decision 1/CP. Appendix $1 \mathrm{c}-$ d).

To be able to participate in, and implement any future activities aimed at reducing emissions from deforestation and forest degradation, developing countries will need national monitoring systems to improve their data collection systems and their estimation and reporting of emissions. The Subsidiary Body for Scientific and Technological Advice (SBSTA) recommended draft decisions on how safeguards are addressed and respected, and modalities related to forest reference emission levels and forest reference levels for adoption by the Convention of Parties at its seventeenth session in Durban (UNFCCC/SBSTA/2011/L.25/Add.1). The document provides principles for national reporting systems. However, there is no detail on how indigenous peoples or local communities can participate in such information systems. Likewise, in its draft decision, the Ad Hoc Working Group on Long-term Cooperative Action under the Convention merely recommends "promot[ing] and support[ing] the safeguards referred to in decision 1/CP.16, Appendix 1, paragraphs 2(c) e)" (AWG-LCA [-/CP.17] 2011).

Despite the intention of full and effective involvement of indigenous peoples and local communities, guidance on how to implement this in practice is wanting. Rather, the UNFCCC REDD+ text notes that "safeguards should support national strategies" and "take into account national circumstances and respective capabilities, and recognizing national sovereignty and legislation, and relevant international obligations and agreements." As it stands, the degree of participation is likely 
Fig. 3. Relationship between the number of plots and the coefficient of variation for forest biomass measurements by community members (stippled red line) and professional foresters (black line) in lowland dipterocarp forest in Batu Majang, Indonesia (a), mountain rain forest in Manlin, China (bc), evergreen monsoon forest in Sakok, Laos (d-e), and Diem (f) and Moi (g), Vietnam (with coefficient of variation $=15 \%$ dashed line; $n=289$ permanent plots). Data from the three sites in Moi were lumped together for the purpose of preparing this figure.
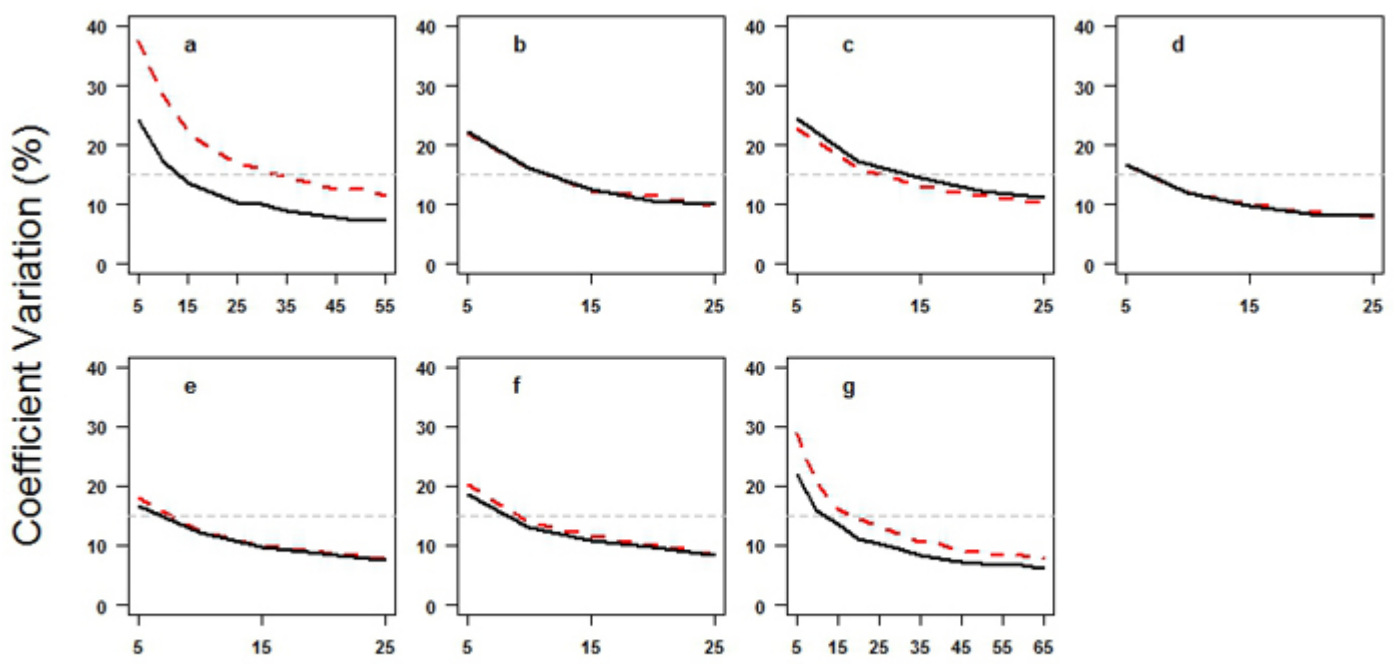

Number of plots

to follow existing national methodologies and policies, and hence may be biased in favor of technocratic solutions to REDD+ needs, and may promote the exclusion of local people. In some instances, however, existing national legal frameworks may favor local involvement, for example in countries with progressive community forestry laws and implementation. In others, the REDD+ text may serve to maintain a low level of community participation. Currently, the limited involvement of local stakeholders in REDD+ monitoring in practice seems to be in contrast to the intended full and effective participation as stated in the UNFCCC REDD+ text.

\section{DISCUSSION}

\section{Scope, strengths, and weaknesses of community monitoring for REDD+}

Following Clark et al. (2011), from a power relations perspective, knowledge products such as REDD+ monitoring results require three attributes before they will be accepted as the basis for negotiations: salience, credibility, and legitimacy. Salience refers to the opportunity to relate results to policies and actions, credibility to the use of correct method and procedure, and legitimacy to the appropriate involvement of stakeholders.
On the salience and legitimacy side, the arguments in favor of involving local communities in monitoring local REDD+ are unequivocal. As greenhouse gas emissions are currently generally the result of the interaction of external and local agents (Meyfroidt and Lambin 2011), local agents will have to be involved in any effort to change from business as usual, and the more this can be discussed on an equal footing and on a level playing field (Agrawal et al. 2011), the higher the chance will be that issues are diagnosed in sufficient depth, solutions are comprehensive, and resistance to change "to meet foreign agendas" is minimized.

On the credibility side, however, there are both challenges and opportunities in combining local knowledge of the environment and the reporting formats needed at the national and international level. In local knowledge systems, quantitative estimates are relevant for estimating how much wood a tree can yield after logging or which species produce good timber or firewood or charcoal, but otherwise, a more qualitative language is often sufficient. Carbon stocks, on the other hand, are abstract concepts and are only relevant insofar as external agents start using these terms and discuss performance-based contracts expressed in such units.

Whereas local REDD+ implementers should not be involved in technical aspects of mathematical calculations of carbon 
Fig. 4. Involvement of local stakeholders in monitoring forest biomass (black), biodiversity (shaded), and livelihoods (white) in forest carbon projects validated by the Climate, Community and Biodiversity Alliance (CCBA) (up to April 13, 2012) ( $n=50$ forest carbon schemes). The degree of involvement of local stakeholders increases from left to right along the $\mathrm{x}$-axis: 1 . no involvement of local stakeholders in monitoring; 2 . local stakeholders assist in, or conduct parts of, monitoring but professional foresters are actively involved in on-the-ground monitoring activities; 3 . local stakeholders conduct all on-the-ground monitoring themselves but reporting and analysis are done by professional foresters; 4 . local stakeholders conduct all onthe-ground monitoring and report the data to a central unit independently, and/or actively participate in the design and implementation phase of the monitoring scheme, and professional foresters conduct the analysis of the monitoring data; 5. local stakeholders participate in the design and implementation phase of the monitoring scheme, conduct all on-the-ground monitoring, and report and analyze all onthe-ground data themselves.

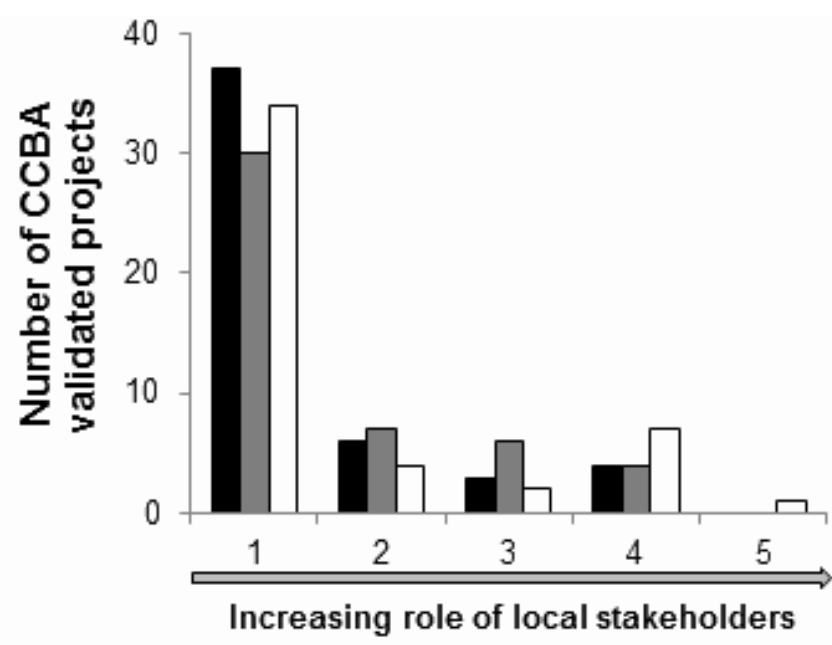

stocks, their involvement in the measurements of forest carbon stocks is likely to secure compensatory payment for standing trees. The clerical skills needed to record tree girth data do not require much beyond primary school reading and writing, but the next steps in processing do. Therefore, biomass monitoring manuals that use look-up tables rather than allometric power functions are very helpful. Hairiah et al. (2011b), in the Indonesian language, cater to this, while the English version (Hairiah et al. 2011a) does not.

Beyond recording the trees in an agreed plot, the process for randomly identifying a plot within an agreed stratum, and a locally fine-tuned approach to stratified sampling are very
Fig. 5. The trend over time in the involvement of local stakeholders in monitoring forest biomass (black triangle), biodiversity (shaded triangle), and livelihoods (white triangle) in forest carbon projects validated by the Climate, Community and Biodiversity Alliance from July 2009 to April 13, 2012 ( $n=50$ forest carbon schemes). The monitoring schemes with local stakeholder involvement belong to categories 2 to 5 in Fig. 4.

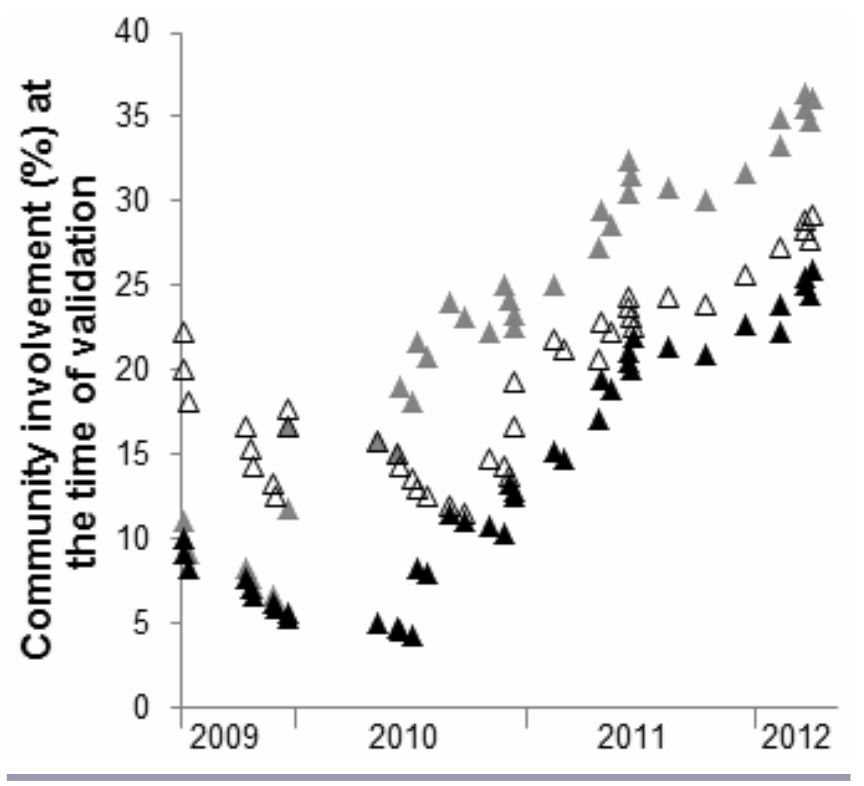

novel concepts at the local level, without obvious local rationale or utility outside of a REDD+ context in the study areas. However, in other countries, like Mexico, where communities are involved in timber harvesting, such forest inventories for volume assessments are commonly carried out (Skutsch 2011). Moreover, there is relatively little space for local adjustments to the community forest biomass monitoring methods. In the worst case, local monitoring degrades to the use of lowly paid or unpaid labor for what is essentially an external agenda. If the REDD+ process leads to other types of important local benefits, this may, however, be justified.

The key opportunity from community monitoring is that it can provide a locally credible estimate of carbon stocks that can directly benefit the local stakeholders.

Quality of data collected through community monitoring In our comparison of community members' and professional foresters' measurements of forest biomass, we found that community members obtained similar forest biomass estimates as professional foresters but with statistically significant bias in three out of nine forest strata that were assessed. However, further analysis revealed that there are easily understandable reasons for this bias. 
When comparing the girth measurements alone, two sites in Laos and one in Vietnam had significant difference between community and forester measurements of girth (Table 1). At these sites, we found small discrepancies across all size classes of trees (Appendix 4 d, e, and i). Likewise, when comparing the tree demarcation alone, there were significant differences between community and forester demarcation of plots at only two sites, one in Indonesia and one in Vietnam (Table 1). One possible explanation for the discrepancies at these sites could be due to a lack of measurement experience; another could be accidental double counting by the professional forester. Another possible explanation is that positioning a plot with a GPS that has a precision of 5-20 $\mathrm{m}$ is difficult. Hence, without marking the trees and the plots, it is difficult to account for the same trees. In complex tropical forests, large trees with buttresses (and the way they have been measured [above/on buttresses]) are likely to cause significant differences in biomass stock assessment. Whatever the reason, with repeated measurements and further training, the capacity of all monitors, community members and foresters alike, should improve, which would reduce the number of errors.

The largest errors recognizable in the data were three notational errors on circumferences (one in Vietnam and two in Indonesia) where trees were assessed as 2-5 $\mathrm{m}$ larger by community monitors than by the foresters. The two plots affected were removed from the analysis of the accuracy of biomass estimates because they were clear erroneous outliers, both from their respective remeasurement results and from the remaining plots in their respective sites. These errors were easily identifiable and occurred in only two out of 289 plots, but they highlight the necessity of proper validation of community measured field data. In other cases, for example in China, difference in community members' and professional foresters' measurements of biomass (Table 1) could be caused by only small but systematic discrepancies in the girth measurements across several size classes of trees (Appendix 4 b). Overall, the numbers of trees found within each size group by community members and foresters were similar, apart from small (32-64 cm circumference) trees in one site (Appendix $4 \mathrm{c})$.

At this and other sites, our observations suggest that particular attention must be paid to training community members in measuring trees with very large or difficult-to-measure stems because inaccuracies in their measurement have a large effect on the biomass estimates. For example, the girth of large trees was sometimes estimated instead of measured due to tall buttresses.

\section{Status of community monitoring in REDD+ schemes}

Our analysis of CCBA validated REDD+ schemes, to our knowledge the first of its kind, shows the gap between policy and practice. In the UNFCCC texts of REDD+ and in the increasing amount of guidance material available, there are strong statements on the need for indigenous people and local communities to be included in the process at national and subnational levels. But our review suggests that the present inclusion of local communities in one of the areas where they are well placed to engage locally based monitoring of forest carbon, biodiversity, and livelihoods is not particularly strong. However, it is improving as projects become more embedded on the ground and it is time to start bringing in those elements that are embodied in the REDD+ safeguards.

In order to further engage local communities in monitoring related to REDD+, and hence improve the social justice of this global mechanism, we suggest further development of methodologies for incorporating indigenous peoples and local communities into the monitoring of REDD+ (Phelps et al. 2010, Fry 2011). Activities can be based on established participatory principles and experience. Hereby, progress may be made towards respecting safeguards using simple techniques that are already available. While our experience is based on site-specific projects, the same basic principles and methods can be applied within subnational projects, possibly as part of the UNFCCC process. This would serve to help close the gap between intentions on participation and field practices within REDD+.

There are some potential biases in our analysis of the level of community involvement in the monitoring of REDD+ within the existing CCBA schemes. For example, some project design documents do not contain the full monitoring plan. It is also sometimes ambiguous which player conducts the monitoring. Therefore, our estimate of community involvement could be conservative. This applies especially to biodiversity and livelihood monitoring but also to some extent carbon monitoring. In addition, the style of the documents also changes through time. They become better at describing the specific role and training of local communities throughout the project, and better at responding to the political decisions at the level of the UNFCCC. Overall, we consider our estimates acceptable for the purposes of this paper, although figures from individual schemes are subject to uncertainty.

\section{Links between national monitoring, reporting, and verification, and community monitoring}

Ideally, community monitoring should be embedded within a process that feeds data to the levels at which subnational and national governments operate. In this section, we describe the links between national REDD+ monitoring, reporting, and verification (MRV) and community monitoring (adapted from Danielsen et al. 2012).

The national REDD+ program should ensure that involved communities are compensated for their labor to avoid taking advantage of local free labor. The involvement of communities in REDD+ MRV must be supported by national policy so that sufficient funds and staff can be set aside for the development 
of the community monitoring component in the national REDD+ program.

In Laos and Vietnam there are already community-based organizations (CBOs), and in China and Indonesia there are individuals with experience in community forest monitoring initiatives. These CBOs, or other institutions representing communities, should be encouraged to take a central role in the design, development, and piloting of the community monitoring component of the national REDD+ program. It is advisable to start small, and see what works, and then expand as experiences accumulate (Herold and Skutsch 2011).

At the national level there is a need for a standard for community forest monitoring so that the same approach is used across all sites throughout the country. The standard should describe the requirements in terms of format of the raw data (measurements of tree girth, wood density) and auxiliary supporting information (location, date). Additional needs for data on forest resource status and forest governance developments should also be described. The standard should also describe how and when the data are transmitted from the $\mathrm{CBO}$ to the government.

The standard should represent a limited number of variables, measured more simply than in a general national inventory. These data should be presented in a form that could dovetail into the national system so that it could condense the nationallevel information by concentrating more sample plots in those areas that are being managed by communities. For example, the national inventory could have permanent plots at $5-\mathrm{km}$ intervals across its entire forest territory, and these plots could then be conglomerates with several sample plots within each of them in which a whole host of variables are measured, once in five years. The community measurements could provide richer (more samples per hectare, and possibly annual measurements) data on carbon, and possibly biodiversity, in those areas where communities are operating. This could also help the decision-makers behind the national program assess whether the community forest management policies being promoted are successful.

Within the national REDD+ program, the specific roles of national staff, CBO staff, and community members should be agreed upon. There should be procedures described on how to collect, verify, check, process, and analyze the data (Pratihast and Herold 2011). Quality checking requires comparison of random spot checks with data sets from other sources. The national REDD+ program should inform the CBOs and communities with regard to signs of displacement of carbon emissions from unplanned forest loss and degradation in adjacent forest areas under REDD+ schemes. It requires process time and strengthened connection between the national REDD+ staff and the CBOs, but this information will be needed for the communities to claim REDD+ credits.
It is important to give government staff time to provide feedback to the communities, not only in terms of questions related to their data but also in terms of helping communities solve the broader land management issues that they experience. There will be a need for regular supervisory visits to the CBOs and communities on the part of the national and subnational REDD+ staff. This can often be appropriately undertaken by government staff with experience in Participatory Rural Appraisal techniques and in holding dialogues with community members.

\section{Will community-based monitoring become a mainstream activity within REDD+ implementation?}

The evidence from the international negotiations over REDD+ strongly suggest that in order for REDD+ to be accepted internationally, local people will have to receive some share of the benefits, whether as cash or development. Therefore, monitoring will be tied to payments or other benefits, and there may be a conflict of interest that has to be resolved.

At present, the majority of community-based forest monitoring schemes were started by research projects or conservation and development projects. Although some of these schemes seem reasonably self-sustaining (Stuart-Hill et al. 2005, Funder et al. in press), they are going to need to be greatly expanded in number, scale, and spread if they are to make any meaningful impact on the field monitoring of REDD+ at global (or even national) scales. We outline some of the ways that this might happen.

For REDD+ that is implemented using community forestry approaches, monitoring by local people could be part of the forest management agreement and tied to payments. However, because there may be incentives to falsify data if the results are linked to financial flows (e.g., Nielsen and Lund 2012), strong third party verification will be required. Experience from community wildlife monitoring, where financial flows are linked to management activities, details how successful benefit sharing has been emerging over the past few years. In the community wildlife management schemes of Namibia, for example, benefits to communities come from hunting and tourism, and the monitoring of wildlife populations, and management events, are wholly community based (event book system). Cross-checks are provided by the government, and there is strong NGO and donor support. This system has been running for more than a decade (Stuart-Hill et al. 2005).

Alternative approaches might also be considered. If we assume that national scale MRV is going to remain an area of technical expertise provided from the remote sensing and forest plot inventory communities, then community-level monitoring will be undertaken in project areas on the ground where there is a strong link between community management of the forest and carbon payments. Simply due to logistical reasons, large scale community-based REDD+ monitoring is unlikely to happen across the vast and remote forests of the Amazon or 
Congo, or the miombo woodlands of Africa. There are simply too few people and too many trees for the approach of community REDD+ monitoring to work. But in areas where there are moderate numbers of people and moderate amounts of remaining forests and management regimes that are community friendly, then the approach has potential. It also seems unlikely that community monitoring will flourish within state managed protected areas. Community-based monitoring can also provide detailed on-the-ground measures to complement the more top-down approaches of remote sensing and inventory plots.

Following from the literature on other kinds of Payment for Ecosystem Service (PES) (Jack et al. 2008) schemes, the theoretical premise of conditionality and direct linkage to output of services in payments is often not upheld, and payments to communities are made on a per hectare basis for kinds of land uses in many cases of what has been described as PES (e.g., Lopa et al. 2012). This annual payment mechanism is simple to administrate and does seem to deliver considerable benefits in terms of changes in land use.

Finally, community monitoring and the detailed data that might be collected can be used to (a) cross-check estimates from remote sensing or models derived from limited numbers of inventory plots, (b) provide community engagement, (c) meet social requirements of REDD+ and ensure that the process is more equitable and just, and (d) convince foresters that there is some useful work that can be done at the community level.

Where REDD+ is implemented using tree planting approaches, there are already many examples of local people measuring trees that they have planted on their farmlands and receiving payment for the growth (and carbon capture) of these trees. Examples of these programs, with periodic third party verification, are provided by TIST (Kenya, Uganda, India: http://tist.org/tist/kenya.php), EcoTrust (Uganda: http:// www.irinnews.org/report/95784/uganda-plant-trees-get-paid), and Scolel Té (Mexico: http://www.planvivo.org/projects/ registeredprojects/scolel-te-mexico/).

In those forms of REDD+ that will be implemented through logging concessions committed to reduced impact logging practices, or through improved management of protected areas, involvement of local communities in the management of the concession or protected area, and hence in any monitoring, will depend on local agreements. The scope for involving local people in monitoring in protected areas and concession areas depends on the extent of community access and rights associated with these areas (as well as the government policies).

Finally, where REDD+ might be implemented through improving the efficiency of biomass burning in kilns for charcoal production or cooking stove efficiency for charcoal and firewood use, project effectiveness measurements might focus on amounts of wood used as firewood for cooking or for the production of a kilogram of charcoal but would still have to be linked to evidence of higher carbon stocks in the landscape. Community-based monitoring of efficiency of production and use of biomass fuel could be established but would be in different form to that outlined above.

To our knowledge, none of the above has been studied in any scientific research, and options for community involvement across the spectrum of potential REDD+ implementation approaches remains an open field for future work.

\section{Could community monitoring promote equitable and "fair" REDD+ implementation?}

Over the past 25 years, developing countries have transitioned toward decentralized forest management that allows local actors increased rights and responsibilities, and this has helped protect forests in many regions (Colfer and Capistrano 2005, Agrawal et al. 2008, Agrawal and Ostrom 2008).

Concerns have been raised that REDD+ is poised to reverse this trend (Phelps et al. 2010). In response to the new global discourses and understandings about unsustainable forest management and the role of forests in climate change mitigation, there is a growing set of international agreements with the potential to bring forests into a whole new fold of global institutions, capital flows, and policies (Sikor 2010). The emergence of new globalization tendencies suggests a need for a fresh look at key forest justice issues. Local participation in monitoring relates to a number of the six themes of forest justice: property, knowledge, governance, social norms of justice, value, and access, as defined by Sikor (2010).

Through participation in monitoring, indigenous peoples and communities may:

1. strengthen their position to gain rights to forests from which they were historically excluded (Larson et al. 2010)

2. feel recognized for their knowledge of forests. They may feel empowered to participate in REDD+ actions on more equal terms (van Laerhoven 2010)

3. be more motivated to contribute to forest protection as they have enhanced trust in the credibility of data and REDD+ actions (Chhatre and Agrawal 2008)

4. derive enhanced benefits from REDD+ either through compensation for the costs of monitoring or through better opportunities for development of benefit-sharing mechanisms (Edwards et al. 2010, Corbera and Schroeder 2011)

5. strengthen their position to obtain or maintain access to culturally and economically important forest areas (Brockington 2007, Schwartzman et al. 2010) 
In short, there are strong reasons of justice as to why communities should be involved in monitoring for REDD+. This corroborates past forestry research that has emphasized the exclusionary nature of (scientific) knowledge on forests (Sikor 2010).

\section{Bottlenecks for scaling up of community monitoring for REDD+}

There are several bottlenecks for the large scale adoption of community approaches to monitoring REDD+. Our study addressed a few issues, but further studies are needed to address these issues more systematically and at larger scale.

In terms of training and capacity building, "technical foresters" are taught mainly professional forestry methods of remote sensing and inventory, while the curriculum for "social foresters" does not prepare them for technical aspects of monitoring carbon stocks (Gregersen et al. 1989). There is low awareness of simple low-tech methods, or the potential benefits of community involvement, among government staff and within NGOs or research institutions.

There are great variations in the skills and motivation of community members to undertake any field-based monitoring work, as clerical skills in recording on paper do not necessarily combine with intimate knowledge of local trees and forest locations. As is found all over the world, some people in communities will be good at doing this work, while others will not be. Choosing the right people, training and motivating them, and keeping them interested is the key to scaling these actions up for the use of REDD+.

Within the scientific community, there also remains a good deal of skepticism about whether, and in what circumstances, and in order to collect what kinds of data, local people can be comparable with foresters. There is a need for further rigorous evaluations of these issues and documentation of what works, and why.

\section{CONCLUSION}

Community involvement in REDD+ receives much attention in the international negotiations on REDD+ policies but is not widely implemented. Of our review of 50 projects under the CCBA standards, $52 \%$ plan to involve communities in monitoring in some way. Although this number has been increasing over time, it remains small and does not truly show commitment from REDD+ project and national implementers to fully involve local communities in this forest management strategy.

A related element of community involvement in REDD+ is the role that community members might play in monitoring on-the-ground activities, including providing reasonably low cost field data from project implementation sites. Involving local communities could contribute to a more just implementation of REDD+. In countries and forest areas where there is a sufficient number of local people capable of measuring trees relative to the task of tree measurement, and where there are sufficient rewards for the time those people would spend on this activity, community-based monitoring approaches could provide useful inputs to national REDD+ programs and the monitoring of forest conservation impacts.

Our findings corroborate previous evidence (Danielsen et al. 2011, Skutsch et al. 2011) that local stakeholders with limited education can monitor forest biomass, and in many circumstances can fulfill the IPCC's highest standards, Tier 3 . Whereas remotely gathered data would be Tier 1 or at best Tier 2 using defaults for biomass stock exchange, local-level data at Tier 3 increase the overall quantity of carbon that the state, the communities, or the private sector could claim internationally.

We obtained similar results for forest biomass when measured by communities and professional foresters in 289 vegetation plots in Southeast Asia. Accuracy concerns regarding community-based approaches in monitoring forest biomass can be addressed by modest investments in training and support.

Our data set extends the previously limited evidence base (125 permanent plots censused by both community members and professional monitors) (Danielsen et al. 2011, Skutsch et al. 2011) with 289 new plots censused by both community members and professional monitors, although the data sets of community members and foresters did not completely match. These studies extend available results from Tanzanian miombo and Himalayan oak and pine community forests to several new forest types, terrains, socioeconomic contexts, and land tenure systems. Forest types differed between tropical lowland forests in Indonesia to monsoon forest in Laos and Vietnam and mountain rain forest in China.

Our study was undertaken in areas where the community members had not, prior to this experiment, recorded forest biomass data regularly. Results cover only the first year of measurements of forest biomass by community members and professional foresters. How the learning curve and changes in commitment will affect results in the coming years remains to be seen. From the results of volunteer-based monitoring in industrialized countries, we know that new participants account for most of the variation in observer reliability (Dickinson et al. 2010), as observers gain increased familiarity with protocols, improved identification skills, and increased awareness of where certain species occur over time.

Our work shows that there is no real need for handheld computers to capture data, but not using them means that data entry has to be completed using Excel or another spreadsheet program in a computer upon return from the field surveys in order to convert tree girth data to biomass (and hence to carbon). This process has to be done either by community 
Table 4. Identified plot level biases in the measurement of aboveground forest biomass by community members and professional foresters, with notes on possible effects and severity of these biases.

\begin{tabular}{|c|c|c|c|c|c|}
\hline Topic & Bias & Effect & $\begin{array}{l}\text { Potential frequency } \\
\text { of occurrence }\end{array}$ & $\begin{array}{l}\text { Severity } \\
\text { when } \\
\text { occurring }\end{array}$ & Remarks \\
\hline \multirow[t]{6}{*}{$\begin{array}{l}\text { Tree } \\
\text { circumference } \\
\text { measurement }\end{array}$} & $\begin{array}{l}\text { Holding thumb under the } \\
\text { measuring tape while } \\
\text { measuring circumference }\end{array}$ & $\begin{array}{l}\text { Increases circumference } \\
\text { measurement }\end{array}$ & Systematic & Medium & $\begin{array}{l}\text { Adds approx. } 2 \mathrm{~cm} \text { depending on } \\
\text { size of tree }\end{array}$ \\
\hline & $\begin{array}{l}\text { For trees on slopes, the } \\
\text { observer might not maintain } \\
\text { the tape perpendicular to the } \\
\text { growth direction of the tree at } \\
\text { point of measurement } \\
\text { (drooping at the back) }\end{array}$ & $\begin{array}{l}\text { Increases circumference } \\
\text { measurement }\end{array}$ & Systematic & Medium & $\begin{array}{l}\text { Adds up to } 4 \mathrm{~cm} \text { depending on size } \\
\text { of tree }\end{array}$ \\
\hline & $\begin{array}{l}\text { Measuring tape sagging on far } \\
\text { side of trees too large to reach } \\
\text { around }\end{array}$ & $\begin{array}{l}\text { Increases circumference } \\
\text { measurement }\end{array}$ & Occasional & Low & $\begin{array}{l}\text { Adds up to } 2 \mathrm{~cm} \text { depending on size } \\
\text { of tree }\end{array}$ \\
\hline & Not removing liana from trees & $\begin{array}{l}\text { Increases circumference } \\
\text { measurement }\end{array}$ & Occasional & Medium & Error proportional to liana size \\
\hline & $\begin{array}{l}\text { Measurement too low above } \\
\text { buttresses or other deformity }\end{array}$ & $\begin{array}{l}\text { Increases circumference } \\
\text { measurement }\end{array}$ & Occasional & Medium & Error proportional to tree size \\
\hline & $\begin{array}{l}\text { Estimating (not measuring) } \\
\text { large or fluted trees or trees } \\
\text { with very high buttresses }(>2 \\
\mathrm{m} \text { ) because of laziness or need } \\
\text { of ladder }\end{array}$ & $\begin{array}{l}\text { Increases or decreases } \\
\text { circumference measurement }\end{array}$ & Occasional & Medium & $\begin{array}{l}\text { Can severely bias biomass estimate } \\
\text { because it affects mainly large } \\
\text { trees }\end{array}$ \\
\hline \multirow[t]{4}{*}{$\begin{array}{l}\text { Plot } \\
\text { demarcation }\end{array}$} & $\begin{array}{l}\text { Including trees smaller than } 94 \\
\mathrm{~cm} \text { circumference in the } 9-15- \\
\mathrm{m} \text { circle, the outer ring of the } \\
\text { circular plot }\end{array}$ & $\begin{array}{l}\text { Increases the number of trees } \\
\text { in the plot }\end{array}$ & Occasional & Medium & $\begin{array}{l}\text { Adds up to } 20 \mathrm{Mg} \text { biomass per } \\
\text { hectare depending on size of tree } \\
\text { and wood density }\end{array}$ \\
\hline & $\begin{array}{l}\text { Change in plot size in steep } \\
\text { slope }\end{array}$ & $\begin{array}{l}\text { Decreases or increases the } \\
\text { number of trees accounted for }\end{array}$ & Systematic & High & \multirow[t]{3}{*}{$\begin{array}{l}\text { Decreases or increases total plot } \\
\text { size }\end{array}$} \\
\hline & $\begin{array}{l}\text { Change in plot size due to } \\
\text { incorrect plot demarcation }\end{array}$ & $\begin{array}{l}\text { Increases or decreases number } \\
\text { of trees in plot }\end{array}$ & Occasional & Medium & \\
\hline & $\begin{array}{l}\text { Rejection of large trees on the } \\
\text { border of the plot }\end{array}$ & $\begin{array}{l}\text { Decreases number of trees in } \\
\text { plot }\end{array}$ & Occasional & High & \\
\hline
\end{tabular}

members with computer skills or by an IO working with communities. Although we found no people skilled in using Excel in any of the communities we worked in, we still feel that this is the simplest approach possible.

Our data show that community monitoring is not necessarily inferior to monitoring by professional foresters in terms of the quality of the data generated. Community monitoring may also be superior in terms of cost effectiveness because we estimate that the costs of community monitoring will decrease over time whereas the costs of forester measurements will remain similar.

There is a need to develop simple standardized methods that can be used at scale and can feed data to national information systems. The work exists as a few, isolated initiatives so far, and there is a great need to embed within national schemes, obtain policy support (i.e., funds and staff set aside), and establish locally suitable standards in each country (Herold and Skutsch 2011). This will take time.
If these approaches are adopted within the implementation of REDD+, periodic third party verification of the monitoring results will be required. This would need to be built into the design and costs of any REDD+ initiative, whether implemented by communities, the State, or the private sector (Danielsen et al. 2011).

Biases observed at the plot level in the field fell into two categories: (i) measurements of tree circumference, and (ii) number of trees included in plot. To help address these potential biases, we have listed all detected aspects of the potential biases in the two categories in Table 4. One of the biases identified was the systematic change in spherical plot sizes when located on steep slopes. Steep to very steep terrain is where probably most remaining forest in Southeast Asia is found today, and this potential bias needs further attention by researchers. 
Responses to this article can be read online at: http://www.ecologyandsociety.org/issues/responses. $\mathrm{php} / 5464$

\section{Acknowledgments:}

The work in Southeast Asia was part of the project Impacts of Reducing Emissions from Deforestation and Forest Degradation and Enhancing Carbon Stocks (I-REDD+) funded by the European Community's Seventh Framework Research Programme (http://www.i-redd.eu). The participation of M.K.P. in Indonesia was funded by Swiss Development Cooperation through the ASEAN-Swiss Partnership on Social Forestry and Climate Change. The work on examining CCBA forest carbon projects was funded by the Netherlands Development Organisation and Nordisk Fond for Miljo og Udvikling. We would like to thank M. Arpels, A. Yanosky, J. Bampton, M. Boissiere, M. Brockhaus, T. Blomley, S. Butchart, J.-C. Castella, S.G. Caviglia, T. Clements, J. Durbin, T. Evans, S. Gomez, K. Hergoualc'h, P. Iversen, M. Kallio, Y. von Laer, H. O. Larsen, A. Lhumeau, C. Maharani, O. Mertz, M. Moeliono, Y. Natori, C. Padoch, A. Rafiastanto, V. Salviati, M. Skutsch, T. Sikor, S. Swan, D. Thomas, L. Verchot, T. Whitten, the CCBA project implementers, and about 95 community members and professional foresters in Indonesia, China, Laos, and Vietnam for their input into the conceptualization of, and data gathering for, this paper.

\section{LITERATURE CITED}

Acharya, K. P. 2002. Twenty-four years of community forestry in Nepal. International Forestry Review 4(2):149156. http://dx.doi.org/10.1505/IFOR.4.2.149.17447

Agrawal, A., A. Chhatre, and R. Hardin. 2008. Changing governance of the world's forests. Science 320:1460-1462. http://dx.doi.org/10.1126/science.1155369

Agrawal, A., D. Nepstad, and A. Chhatre. 2011. Reducing emissions from deforestation and forest degradation. Annual Review of Environment and Resources 36:373-396. http://dx. doi.org/10.1146/annurev-environ-042009-094508

Agrawal, A., and E. Ostrom. 2008. Decentralization and community based forestry: learning from experience. Pages 44-67 in E. L. Webb and G. Shivakoti, editors. Decentralization, forests and rural communities: policy outcomes in South and Southeast Asia. SAGE, New Delhi, India.

Andrianandrasana, H. T., J. Randriamahefasoa, J. Durbin, R. E. Lewis, and J. H. Ratsimbazafy. 2005. Participatory ecological monitoring of the Alaotra wetland in Madagascar.
Biodiversity and Conservation 14:2757-2774. http://dx.doi. org/10.1007/s10531-005-8413-y

Angelsen, A., D. Boucher, S. Brown, V. Merckx, V., C. Steck, and Z. Darin. 2011. Modalities for REDD+ reference levels: technical and procedural issues. The Meridian Institute, Washington, D.C., USA.

Angelsen, A., M. Brockhaus, M. Kanninen, E. Sills, W. D. Sunderlin, and S. Wertz-Kanounnikoff, editors. 2009. Realising REDD+: national strategy and policy options. Center for International Forestry Research (CIFOR), Bogor, Indonesia.

Anon. 2012a. Population data, Nepal. [online] URL: http:// www.populationdata.net/index2.php?lang=EN\&option= pays\&pid $=149 \&$ nom $=$ nepal

Anon. 2012b. Database. Department of Forest, Ministry of Forests and Soil Conservation, Nepal. [online] URL: http:// dof.gov.np/division/community-forest-division/community-forestry

Asner, G. P., G. V. N. Powell, J. Mascaro, D. E. Knapp, J. K. Clark, J. Jacobson, T. Kennedy-Bowdoin, A. Balaji, G. PaezAcosta, E. Victoria, L. Secada, M. Valqui, and R. F. Hughes. 2010. High-resolution forest carbon stocks and emissions in the Amazon. Proceedings of the National Academy of Sciences USA 107(38):16738-16742. http://dx.doi.org/10.1073/ pnas. 1004875107

Brockington, D. 2007. Forests, community conservation, and local government performance: the village forest reserves of Tanzania. Society \& Natural Resources 20:835-848. http:// dx.doi.org/10.1080/08941920701460366

Brown, S. 1997. Estimating biomass and biomass change of tropical forests: a primer. FAO Forestry Paper 134, Food and Agriculture Organization of the United Nations, Rome.

Carter, J., and J. Gronow. 2005. Recent experience in collaborative forest management: a review paper. CIFOR Occasional Paper No. 43. Center for International Forestry Research (CIFOR), Jakarta, Indonesia.

Chhatre, A., and A. Agrawal. 2008. Forest commons and local enforcement. Proceedings of the National Academy of Sciences USA 105(36):13286-13291. http://dx.doi.org/10.1073/ pnas.0803399105

Chhatre, A., and A. Agrawal. 2009. Trade-offs and synergies between carbon storage and livelihood benefits from forest commons. Proceedings of the National Academy of Sciences USA 106(42):17667-17670. http://dx.doi.org/10.1073/ pnas.0905308106

Clark, W. C., T. P. Tomich, M. van Noordwijk, D. Guston, D. Catacutan, N. M. Dickson, and E. McNie. 2011. Boundary 
work for sustainable development: natural resource management at the Consultative Group on International Agricultural Research (CGIAR). Proceedings of the National Academy of Sciences USA 10:1073. http://dx.doi.org/10.1073/ pnas.0900231108

Climate, Community and Biodiversity Alliance (CCBA). 2008. Climate, community and biodiversity project design standards. Second edition. Arlington, Virginia, USA.

Colfer, P. C. J., and D. Capistrano. 2005. The politics of decentralization: forests, power, and people. Earthscan, London, UK.

Corbera, E., and H. Schroeder. 2011. Governing and implementing REDD+. Environmental Science \& Policy 14:89-99. http://dx.doi.org/10.1016/j.envsci.2010.11.002

Dam, P., and E. Trines. 2011. Can carbon compete with the loggers in Papua New Guinea? Pages 158-168 in M. Skutsch, editor. Community forest monitoring for the carbon market. Earthscan, London, UK.

Danielsen, F., N. D. Burgess, and A. Balmford, editors. 2005. Monitoring matters: examining the potential of locally-based approaches. Biodiversity and Conservation 14:2507-2820. http://dx.doi.org/10.1007/s10531-005-8375-0

Danielsen, F., N. D. Burgess, A. Balmford, P. F. Donald, M. Funder, J. P. Jones, P. Alviola, D. S. Balete, T. Blomley, J. Brashares, B. Child, M. Enghoff, J. Fjeldså, S. Holt, H. Hübertz, A. E. Jensen, P. M. Jensen, J. Massao, M. M. Mendoza, Y. Ngaga, M. K. Poulsen, R. Rueda, M. Sam, T. Skielboe, G. Stuart-Hill, E. Topp-Jørgensen, and D. A. Yonten. 2009. Local participation in natural resource monitoring: a characterization of approaches. Conservation Biology 23:31-42. http://dx.doi.org/10.1111/j.1523-1739.2008.01063. $\underline{\mathrm{X}}$

Danielsen, F., N. D. Burgess, and M. Enghoff. 2012. From global to local in REDD+ MRV: linking community and government approaches. Pages 273-274 in A. Angelsen, editor. Analysing REDD + challenges and choices. Center for International Forestry Research (CIFOR), Jakarta, Indonesia.

Danielsen, F., N. D. Burgess, P. M. Jensen, and P. PirhoferWalzl. 2010. Environmental monitoring: the scale and speed of implementation varies according to the degree of peoples involvement. Journal of Applied Ecology 47:1166-1168. http://dx.doi.org/10.1111/j.1365-2664.2010.01874.x

Danielsen, F., M. M. Mendoza, A. Tagtag, P. A. Alviola, D. S. Balete, A. E. Jensen, M. Enghoff, and M. K. Poulsen. 2007. Increasing conservation management action by involving local people in natural resource monitoring. Ambio 36:566570. http://dx.doi.org/10.1579/0044-7447(2007)36[566:ICMABI] 2.0.CO;2
Danielsen, F., M. D. Skutsch, N. D. Burgess, P. M. Jensen, H. Andrianandrasana, B. Karky, R. Lewis, J. C. Lovett, J. Massao, Y. Ngaga, P. Phartiyal, M. K. Poulsen, S. P. Singh, S. Solis, M. Sørensen, A. Tewari, R. Young, and E. Zahabu. 2011. At the heart of REDD+: a role for local people in monitoring forests? Conservation Letters 4:158-167. http://dx.doi. org/10.1111/j.1755-263X.2010.00159.X

Dickinson, J. L., B. Zuckerberg, and D. N. Bonter. 2010. Citizen science as an ecological research tool: challenges and benefits. Annual Review of Ecology, Evolution, and Systematics 41:149-172. http://dx.doi.org/10.1146/annurevecolsys-102209-144636

Edwards, D. P., B. Fisher, and E. Boyd. 2010. Protecting degraded rainforests: enhancement of forest carbon stocks under REDD+. Conservation Letters 3:313-316. http://dx. doi.org/10.1111/j.1755-263X.2010.00143.X

Epple, C., E. Dunning, B. Dickson, and C. Harvey. 2011. Making biodiversity safeguards for REDD+ work in practice. Developing operational guidelines and identifying capacity requirements. United Nations Environment Program-World Conservation Monitoring Centre, Cambridge, UK.

Fisher, B., S. L. Lewis, N. D. Burgess, R. E. Malimbwi, P. K. Munishi, R. D. Swetnam, R. K. Turner, S. Willcock, and A. Balmford. 2011. Implementation and opportunity costs of reducing deforestation and forest degradation in Tanzania. Nature Climate Change 1:161-164. http://dx.doi.org/10.1038/ nclimate1119

Forest Peoples Program (FPP). 2012. Forest Peoples Program comments on the draft UNREDD FPIC guidelines. Moretonin-Marsh, UK. [online] URL http://www.forestpeoples.org/ sites/fpp/files/publication/2012/01/unreddfpicsubmissionfinaljan20. $\underline{\mathrm{pdf}}$

Fry, B. 2011. Community forest monitoring in REDD+: the 'M' in MRV? Environmental Science and Policy 14:181-187.

Funder, M., F. Danielsen, Y. Ngaga, M. R. Nielsen, and M. $\mathrm{K}$. Poulsen. In press. Reshaping conservation: the social dynamics of participatory monitoring in Tanzania's community-managed forests. Conservation \& Society.

Gardner, T. A., N. D. Burgess, N. Aguilar-Amuchastegui, J. Barlow, E. Berenguer, T. Clements, F. Danielsen, F. Ferreira, F. Foden, A. C. Lees, M. R. Roman-Cuesta, L. Parry, C. B. Schmitt, N. Strange, S. M. Khan, I. Theilade, and I. C. G. Vieira. 2012. A framework for integrating biodiversity concerns into national REDD+ programmes. Biological Conservation 154:61-71. http://dx.doi.org/10.1016/j. biocon.2011.11.018

Ghazoul, J., R. Butler, J. Mateo-Vega, and L. P. Koh. 2010. REDD: a reckoning of environment and development 
implications. Trends in Ecology and Evolution 25:396-402. http://dx.doi.org/10.1016/j.tree.2010.03.005

Gibson, C. C., J. T. Williams, and E. Ostrom. 2005. Local enforcement and better forests. World Development 33:273284. http://dx.doi.org/10.1016/j.worlddev.2004.07.013

GOFC-GOLD. 2010. A sourcebook of methods and procedures for monitoring and reporting anthropogenic greenhouse gas emissions and removals caused by deforestation, gains and losses of carbon stocks in forests remaining forests, and forestation. GOFC-GOLD Report, version COP 16-1, Alberta, Canada.

Gregersen, H., S. Draper, and D. Elz, editors. 1989. People and trees. The role of social forestry in sustainable development. $\mathrm{CAB}$ International, Wallingford, UK.

Hairiah, K., S. Dewi, F. Agus, S. J. Velarde, A. Ekadinata, S. Rahayu, and M. van Noordwijk. 2011a. Measuring carbon stocks across land use systems: a manual. World Agroforestry Centre-ICRAF, South East Asia Regional Office, Bogor, Indonesia.

Hairiah, K., A. Ekadinata, R. R. Sari, and S. Rahayu. $2011 b$. Pengukuran cadangan karbon dari tingkat lahan ke bentang lahan. Second edition. World Agroforestry Centre-ICRAF, South East Asia Regional Office, Bogor, Indonesia.

Herold, M., and M. Skutsch. 2011. Monitoring, reporting and verification for national REDD + programmes: two proposals. Environmental Research Letters 6(1):014002.

Howell, S. 2012. No rights-no REDD: the credibility gap between intention and execution. Beyond carbon: enabling justice and equity in REDD+ across levels of governance, 2324 March 2012, St. Anne's College, Oxford, UK. [online] URL http://www.eci.ox.ac.uk/redd/downloads/ppt/3-2-howell.pdf

Jack, B. K., C. Kousky, and K. R. E. Sims. 2008. Designing payments for ecosystem services: lessons from previous experience with incentive-based mechanisms. Proceedings of the National Academy of Sciences USA 105:9465-9470.

Kanel, K. R. 2004. Twenty-five years' of community forestry: contribution to Millennium Development Goals. 4th National Community Forestry Workshop, 4-6 August, 2004, Kathmandu, Nepal. Ministry of Forests and Soil Conservation, Kathmandu, Nepal.

Koleff, P., K. J. Gaston, and J. J. Lennon. 2003. Measuring beta diversity for presence-absence data. Journal of Animal Ecology 72(3):367-382. http://dx.doi.org/10.1046/ j.1365-2656.2003.00710.x

Larson, A., D. Barry, G. Dahal, and C. Colfer, editors. 2010. Forests for people: community rights and forest tenure reform. Earthscan, Washington, D.C., USA.
Lopa, D., I. Mwanyoka, G. Jambiya, T. Massoud, P. Harrison, M. Ellis-Jones, T. Blomley, B. Leimona, M. van Noordwijk, and N. D. Burgess. 2012. Towards operational payments for water ecosystem services in Tanzania: a case study from the Uluguru Mountains. Oryx 46:34-44.

Merger, E., M. Dutschke, and L. Verchot. 2011. Options for REDD+ voluntary certification to ensure net GHG benefits, poverty alleviation, sustainable management of forests and biodiversity conservation. Forests $2: 550-577$. http://dx.doi. org/10.3390/f2020550

Meyfroidt, P., and E. Lambin. 2011. Global forest transition: prospects for an end to deforestation. Annual Review of Environment and Resources 36:343-371. http://dx.doi. org/10.1146/annurev-environ-090710-143732

Mukama, K., I. Mustalahti, and E. Zahabu. 2012. Participatory forest carbon assessment and REDD+: learning from Tanzania. International Journal of Forestry Research 2012:126454.

Nielsen, M. R., and J. F. Lund. 2012. Seeing white elephants? The production and communication of information in a locally-based monitoring system in Tanzania. Conservation \& Society 10(1):1-14. http://dx.doi.org/10.4103/0972-4923.92188

Penman, J., M. Gytarsky, T. Hiraishi, T. Krug, D. Kruger, R. Pipatti, L. Buendia, K. Miwa, T. Ngara, K. Tanabe, and F. Wagner, editors. 2003. Good practice guidance for land use, land-use change and forestry. IPCC National Greenhouse Gas Inventories Programme and Institute for Global Environmental Strategies, Kanagawa, Japan. [online] URL http://www.ipccnggip.iges.or.jp/public/gpglulucf/gpglulucf contents

Peters-Guarin, G., and M. K. McCall. 2011. Participatory mapping and monitoring of forest carbon services using freeware: Cyber Tracker and Google Earth. Pages 94-104 in M. Skutsch, editor. Community forest monitoring for the carbon market. Earthscan, London, UK.

Phelps, J., E. L. Webb, and A. Agrawal. 2010. Does REDD+ threaten to recentralize forest governance? Science 328:312313. http://dx.doi.org/10.1126/science.1187774

Pratihast, A. K., and M. Herold. 2011. Community based monitoring and potential links with national REDD+ MRV. Proceedings of the FCPF workshop-Linking community monitoring with national MRV for REDD+. CIGA-UNAM, Mexico City, Mexico, 12-14 September 2011.

Preacher, K. J. 2001. Calculation for the chi-square test: an interactive calculation tool for chi-square tests of goodness of fit and independence. [online] URL http://www.quantpsy.org/ chisq/chisq.htm 
Putz, F. E., and K. H. Redford. 2009. Dangers of carbon-based conservation. Global Environmental Change 19:400-401. http://dx.doi.org/10.1016/j.gloenvcha.2009.07.005

Rights and Resources. 2010. The end of the hinterland forests, conflict and climate change. Rights and Resources Initiative, Centre for People and Forests, Forest Peoples Programme, World Agroforestry Centre, Nairobi, Kenya.

Robledo, C., J. Blaser, S. Byrne, and K. Schmidt. 2008. Climate change and governance in the forest sector. Rights and Resources Initiative, Washington, D.C., USA.

Rutishauser E., F. Noor'an, A. Rufi'ie, J. Halperin, and Y. Laumonier. In press. Accurate estimates of carbon stocks for carbon credits: how much do allometric models matter? Ecological Applications

Schwartzman, S., A. Alencar, and A. P. S. Souza. 2010. Social movements and large scale tropical forest protection on the Amazon frontier: conservation from chaos. Journal of Environmental Research and Development 19:174-299.

Sikor, T. 2010. Forest justice: towards a new agenda for forest research and practice? Journal of Integrative Environmental Sciences 7(4):245-250. http://dx.doi.org/10.1080/1943815X.2010.530878

Skutsch, M., editor. 2011. Community forest monitoring for the carbon market. Earthscan, London, UK.

Skutsch, M., E. Zahabu, B. Karky, and F. Danielsen. 2011. The costs and reliability of community forestry monitoring. Pages 73-81 in M. Skutsch, editor. Community forest monitoring for the carbon market. Earthscan, London, UK.

Strassburg, B. B. N., A. S. L. Rodrigues, M. Gusti, A. Balmford, S. Fritz, M. Obersteiner, R. K. Turner, and T. M. Brooks. 2012. Impacts of incentives to reduce emissions from deforestation on global species extinctions. Nature Climate Change 2(5):350-355.

Stuart-Hill, G., R. Diggle, B. Munali, J. Tagg, and D. Ward. 2005. The event book system: a community-based natural resource monitoring system from Namibia. Biodiversity and Conservation 14:2611-2631. http://dx.doi.org/10.1007/ s10531-005-8391-0

United Nations Framework Convention on Climate Change (UNFCCC). 2011a. Outcome of the work of the ad hoc working group on long-term cooperative action under the convention. Draft decision [-/CP.17]. UNFCCC, Bonn, Germany.

United Nations Framework Convention on Climate Change (UNFCCC). 2011b. Framework Convention on Climate Change, Subsidiary Body for Scientific and Technological Advice (SBSTA), Methodological guidance for activities relating to reducing emissions from deforestation and forest degradation and the role of conservation, sustainable management of forests and enhancement of forest carbon stocks in developing countries. Draft conclusions proposed by the Chair, Thirty-fifth session Durban, 28 November to 3 December 2011, UNFCCC, Bonn, Germany.

UN-REDD. 2011. UN-REDD guidelines on free, prior and informed consent (FPIC). [online] URL http://www.un-redd. org/Launch of FPIC Guidlines/tabid/105976/Default.aspx

van Laerhoven, F. 2010. Governing community forests and the challenge of solving two-level collective action dilemmas - a large- $N$ perspective. Global Environmental Change 20 (3):539-546. http://dx.doi.org/10.1016/j.gloenvcha.2010.04.005

Venter, O., W. F. Laurance, T. Iwamura, K. A. Wilson, R. A. Fuller, and H. P. Possingham. 2009. Harnessing carbon payments to protect biodiversity. Science 326:1368. http://dx. doi.org/10.1126/science.1180289

Verplanke, J., and E. Zahabu. 2009. A field guide for assessing and monitoring reduced forest degradation and carbon sequestration by local communities. KTGAL Project, Enschede, Netherlands.

Wagner, F., E. Rutishauser, L. Blanc, and B. Herault. 2010. Effects of plot size and census interval on descriptors of forest structure and dynamics. Biotropica 42:664-671. http://dx.doi. org/10.1111/j.1744-7429.2010.00644.x 
APPENDIX 1. Study areas.

We compared above ground biomass from one forest stratum in Indonesia, two forest strata in China, two forest strata in Laos, and four forest strata in Vietnam.

In Indonesia, the study area was located in Kutai Barat District, in the Province of East Kalimantan. Monitoring plots are located in tropical lowland rainforest at 40-500 m.a.s.I. characterised by species of the Dipterocarp family such as Shorea spp., Dipterocarpus spp., Anisoptera spp., and Hopea spp., in addition to other high quality timber species. The canopy is $30-40 \mathrm{~m}$ tall and maximum DBH is $150-270$ $\mathrm{cm}$. Community members and scientists measured one forest stratum of 400 ha, in mainly primary forest in hilly terrain. Slope inclinations ranged between $30^{\circ}$ and $70^{\circ}$, and in some areas attained up to $90^{\circ}$. Some areas closer to the village were logged recently and consisted of secondary forest. The area is customary forest of the Batu Majang village. The local community is committed to conserving this forest in order to protect the watershed and their water resources.

In China, the study area was near Man Lin village in Xiangming township of Xishuangbanna Autonomous Prefecture, Yunnan Province. The climate is monsoonal with an average annual temperature of $25^{\circ} \mathrm{C}$ and an average annual precipitation of $1700 \mathrm{~mm}$. The vegetation is tropical mountain rainforest at around 900-1200 m.a.s.I. The forest is characterised by Pometia tomentosa, Castanopsis spp., Dysoxylum gobara and Knema cinerea. The canopy can be divided into 3 layers: the overstory reaches $35 \mathrm{~m}$ in height and is dominated by Pometia tomentosa; the mid-story reaches $25 \mathrm{~m}$ and is dominated by Castanopsis spp., and Schima wallichii while the understory contains a multitude of species, such

as Machilus spp., Lithocarpus spp., Elaeocarpus spp., and Mallotus spp. Shrub and herbaceous layers at the edges and inside some forest areas are rich in species. Slope inclinations ranged between $30^{\circ}$ and $70^{\circ}$, and up to $90^{\circ}$ in some areas. Two forest strata were measured. The stratum closer to the village (291 ha) consisted of abandoned shifting cultivation fields and ancient tea trees with an overstory of natural forest. It is classified as collective forest. The second stratum (470 ha) consisted mainly of natural forest on steep to very steep slopes. The area was logged 40-60 years ago. Shifting cultivation was practiced from the 1950 s to the 1990 s and then gradually abandoned. The forest recovered in steeper areas and is today state forest. Selective harvest of a few valuable timber species is currently taking place but there is hardly any illegal cutting and the forest is in a good condition with profusion of lianas and epiphytes.

In Laos, the study area was located in Ban Sakok village, Viengthong District, Hauphan Province. The climate is tropical monsoon climate with two main seasons: a wet season from May to September and a dry season from October to April. Due to the high altitude, temperatures drop to zero and frost can occur between December and February. The precipitation ranges from 1,600 to 1,800 mm per year, mainly confined to the wet season. Monitoring plots were located in evergreen open and closed broadleaved monsoon forest including patches of evergreen shrub at lower elevations next to old swidden fields east of Ban Sakok village at 600 -1600 m.a.s.l. The canopy was 25-35 meters tall and the maximum DBH were 70 to $90 \mathrm{~cm}$. The forest is characterised by Castanopsis tribuloides, Schima wallichii, Quercus kerrii, Lithocarpus truncatus, Nauclea orientalis, Engelhardtia spicata, Syzygium cumini, Ficus auriculata, Palaquium spp., Pterospermum spp., and Wendlandia spp. as dominant species. Two strata were surveyed, representing mainly closed forest (100 ha) and open forest (62 ha) with small areas of evergreen shrub forest at lower elevations. Slope inclinations ranged between $0^{\circ}$ and $45^{\circ}$, and in some areas up to $60^{\circ}$. The forest areas were not designated as community forest, but the local community did have user rights issued by the local national park authority.

The study areas in Vietnam were located in Con Cuong District, Nghe An Province near Diem and Moi villages. The climate is monsoonal with an average annual temperature of $23.5^{\circ} \mathrm{C}$ and an average annual precipitation of $1790 \mathrm{~mm}$. The rainy season lasts from April to October with a peak in August to September. Plots were located in secondary evergreen broadleaved forest at 160-460 m.a.s.I. The canopy was 15-25 m tall with maximum DBH of 150-270 cm. Characteristic species were Cullen corylifolium, Ficus racemosa, Ormosia balansae, Castanopsis indica, Vatica subglabra and Knema erratica. Clusters of bamboo were found at the edges and scattered inside the strata covering about 10$15 \%$ of the area. The terrain is rugged with slopes ranging mostly from $30^{\circ}$ to $60^{\circ}$ inclination. All forest strata were degraded to severely degraded. The forestland was allocated to village households in 1999 by the district authorities. Before land allocation to villagers, the forest was managed by the commune and shifting cultivation was common. Since 1999, shifting cultivation has decreased significantly while investment in forest plantations has gradually increased. One forest stratum at Diem village (67 ha) and three strata at Moi village $(125,104,18$ ha) were surveyed consisting of a total of 314 ha. The stratum 
in Diem mainly covers open secondary forest that has regenerated since the 1980s. Shifting cultivation and timber extraction is still practiced in some areas. In Moi village, shifting cultivation completely ceased after the land allocation to villagers in 1999 but harvesting of timber still happens. Land cover has gradually changed from swidden fields and fallows to closed secondary forest with most trees more than 10 years old.

In the 'Methods' and this appendix, we have used the term 'closed forest'. Closed forest is defined as > $65 \%$ canopy cover and open forest as less than $65 \%$ canopy according to the classification by Di Gregorio (2005).

\section{Literature cited}

Di Gregorio, A. 2005. Land cover classification system: Classification concepts and user manual for software - version 2. Food \& Agriculture Organization of the United Nations, Rome, Italy. 
Appendix 2. Description of the methods used to collect forest biomass data.

\begin{tabular}{|c|c|c|c|c|c|}
\hline $\begin{array}{c}\text { Training provided } \\
\text { to the community } \\
\text { members }\end{array}$ & $\begin{array}{l}\text { Manual for professional trainers and check-list for } \\
\text { community members }\end{array}$ & $\begin{array}{c}\text { Data processing by } \\
\text { community } \\
\text { members }\end{array}$ & $\begin{array}{l}\text { Timing and } \\
\text { location } \\
\text { of the data } \\
\text { collection }\end{array}$ & Equipment & Definitions \\
\hline $\begin{array}{l}\text { An intermediary } \\
\text { organisation } \\
\text { trained community } \\
\text { members in the use } \\
\text { of GPS functions to } \\
\text { mark the } \\
\text { boundaries of the } \\
\text { forest strata and to } \\
\text { locate the } \\
\text { permanent plots. } \\
\text { Teams of } 3-7 \\
\text { community } \\
\text { members were } \\
\text { trained for } 1-2 \\
\text { days. }\end{array}$ & $\begin{array}{l}\text { A manual for establishing and implementing } \\
\text { community monitoring of biomass has been produced } \\
\text { to guide the professional trainers. This manual also } \\
\text { includes all information a professional forester needs } \\
\text { for conducting monitoring of biomass, including } \\
\text { information on how to map forest strata, how to use } \\
\text { measurements from pilot plots to calculate the number } \\
\text { of plots needed within each stratum, how to measure } \\
\text { the trees, etc. The villagers are not expected to read this } \\
\text { manual and a check-list has been produced to help the } \\
\text { villagers remember what they have learned during the } \\
\text { training. } \\
\text { Check-list. Before going to the forest: } 1 . \text { Organise the } \\
\text { team members; } 2 \text {. Check the equipment. } 3 \text {. Purchase } \\
\text { ropes with } 9 \text { and } 15 \text { m marked on them; } \\
\text { In the forest: } 4 \text {. Locate plot; } 5 \text {. Mark trees; } 6 \text {. Measure } \\
\text { trees; } 7 \text {. Enter data in form. } \\
\text { Back in village: } 8 . \text { Copy forms; } 9 . \text { Store forms safely; } \\
10 . \text { Hand forms to intermediate organisation. } \\
\text { In Laos and Vietnam, community members numbered } \\
\text { each tree individually, and these were re-measured by } \\
\text { the foresters. }\end{array}$ & $\begin{array}{l}\text { Field data forms were } \\
\text { checked by } \\
\text { community members } \\
\text { and handed over to an } \\
\text { intermediary } \\
\text { organisation who } \\
\text { processed the data } \\
\text { (and who returned the } \\
\text { results to the } \\
\text { community). }\end{array}$ & $\begin{array}{l}\text { Community } \\
\text { monitoring: } \\
\text { Indonesia (Sep. } \\
\text { 2011), China } \\
\text { (Nov. 2011), Laos } \\
\text { (Feb. 2012), } \\
\text { Vietnam, Moi } \\
\text { (Oct.-Nov. 2011), } \\
\text { Vietnam, Diem } \\
\text { (Nov.-Dec. 2011). } \\
\text { Professional } \\
\text { monitoring: } \\
\text { Indonesia (Sep. } \\
\text { 2011 - Jan. 2012), } \\
\text { China (Nov.-Dec. } \\
\text { 2011), Laos (May } \\
\text { 2012), Vietnam, } \\
\text { Moi (Jan. 2012), } \\
\text { Vietnam, Diem } \\
\text { (Jan. 2012). }\end{array}$ & $\begin{array}{l}\text { GPS } \\
\text { device, } \\
\text { ordinary } \\
\text { measuring } \\
\text { tape, rope } \\
\text { for } \\
\text { measuring } \\
\text { plots, paint, } \\
\text { field forms, } \\
\text { pencil. }\end{array}$ & $\begin{array}{l}\text { By forest } \\
\text { stratum, we } \\
\text { mean a } \\
\text { 'homogenous } \\
\text { forest area in } \\
\text { terms of tree } \\
\text { species } \\
\text { composition } \\
\text { and level of } \\
\text { degradation'. } \\
\text { By DBH, we } \\
\text { mean } \\
\text { 'diameter at } \\
\text { breast } \\
\text { height' of the } \\
\text { main stem of } \\
\text { the tree. }\end{array}$ \\
\hline
\end{tabular}


APPENDIX 3. Details of how the costs of community and forester-collected forest biomass data were calculated.

Calculations of the costs of community and professional monitoring of forest biomass were prepared by MKP using actual costs in each of the four countries for the first year of monitoring. In this appendix, we describe how the calculations were made. For the costs of the training and supervision, we included all the expenses of the training personnel (travel, accommodation, food and wages). The costs of monitoring for years 2-4 were estimated. Equipment includes measuring tapes, paint, rope, field forms, marker pens and similar. At some sites it was necessary to buy a GPS device but the price of these is not included here. The costs of the professional foresters were estimated as being almost the same every year. All values are in USD at exchange rates as of April 2012.

\section{(1) Indonesia}

Currency: IDR 1,000 = USD 0.11 (April 2012).

\section{Community monitoring}

Training and supervision:

Travel: The cost of transport for three trainers from Barong was USD 825 (IDR 7,500,000).

Accommodation: Accommodation for the three trainers was USD 149 ( 3 x 9 nights at IDR 50,000).

Food: Two cooks were employed for 10 days and paid IDR 1,400,000 but only a part of this cost (USD 248) related to the trainers.

Wages: Three trainers received a total of USD 990 (USD 33 per day for each trainer, 10 days).

Years 2-4: For the following years, only one trainer is needed and the cost of training is consequently reduced.

Transport costs USD 275. Food costs USD 83. Wages for one trainer is USD 330. Accommodation for the trainers costs USD 50 (9 nights at IRD 50,000).

Implementation (by community members):

Food: The cost of food for community members was USD 146 (53 lunch packs at IDR 25,000 each were consumed by community members during the field work).

Equipment: The cost of materials such as paint, rope, batteries and stationery was USD 48. GPS devices were borrowed.

Wages for community members: A total of USD 435 was paid in salaries to community members for monitoring (53 person-days at IDR 70,000-100,000, totalling IDR 3,950,000).

Years 2-4: It is estimated that the costs of implementation by community members (food for data gatherers and wages) will reduce by $25 \%$ as the plots are already established. Equipment will come to around USD 10 per year.

\section{Professional monitoring}

Travel and accommodation: The cost of travel and accommodation for the professional monitor was USD 385 (IDR 2,500,000 for transport between Barong and Batu Majang, and IDR 1,000,000 for boat).

Food: The total cost of per diems and food for professional monitoring was USD 353. The forester was paid IDR 75,000 (USD 8.25) for food per day for 24 days (USD 198); the villagers assisting the forester were provided with food worth IDR 25,000 (USD 2.92) per day for 53 person-days of field work (USD 155).

Equipment: An estimated USD 15 was paid for equipment.

Wages: The forester was paid a salary of IDR 300,000 (USD 33) per day when working in the forest and IDR 250,000 (USD 27.5) per day for travelling/village days. The total salary was USD 765 for the professional forester and USD 1,122 for the villagers assisting the forester.

Years 2-4: Travel and accommodation are estimated to remain at USD 385 per year but food and wages can be reduced to USD 265 per year (food) and USD 904 per year (wages). Equipment will be approx. USD 10 per year.

\section{(2) China}

Currency: Rmb 1 = USD 0.16 (April 2012).

\section{Community monitoring}

$\underline{\text { Training and supervision: }}$ 
Travel: This calculation is based on the cost of three trainers, one from Kunming and two from Jinghong. The air fare Kunming-Jinghong-Kunming for one trainer was USD 333. The shared car Jinghong-Manlin and Manlin-Jinghong was USD 128 (renting a local car cost Rmb 400 per day, so a round trip was Rmb 800). The total cost of travel was USD 461.

Accommodation: Three persons for one night at Rmb 100 per person in Jinghong cost USD 48; and 8 nights in Manlin at Rmb 20 per person came to Rmb 780 or USD 125. Total: USD 173.

Food: Three persons at Rmb 30 for ten days totalled Rmb 900 or USD 144.

Wages: The daily fee for each trainer was USD 48 (Rmb 300). The three trainers were needed for 10 days (USD 1,440). Years 2-4: In subsequent years, only one trainer from Jinghong will be needed. The cost of the training will consequently reduce. Car cost of USD 128, accommodation and food for one trainer at USD 88 (8 x USD 11), and salary of USD 384 (8 x USD 48).

Implementation (by community members):

Food: Community members took responsibility for their own food.

Equipment: An estimated USD 20 was spent on paint, rope and batteries. GPS devices were borrowed.

Wages for community members: Each villager received a daily salary of Rmb 100 (USD 16) when working in the forest on establishing plots and measuring trees. The total effort made by villages came to 24 person-days, costing USD 384 .

\section{Professional monitoring}

Travel and accommodation: The air fare Kunming-Jinghong-Kunming for the professional monitor was USD 333, and the taxi Jinghong-Manlin and Manlin-Jinghong was USD 51. The cost of accommodation in Manlin for the professional monitor was USD 32 for all 10 days.

Food: Food in Manlin for the professional monitor cost $30 \mathrm{Rmb} / \mathrm{day}$. Food for ten days thus cost Rmb 300 or USD 48. Equipment: All equipment was borrowed.

Wages: The daily salary of a professional monitor was USD 58. The professional monitor was needed for 10 days, which cost USD 580. Two local assistants were paid Rmb 100 (USD 16) per day for 8 days and they therefore cost USD 128 each. The total wages were USD 836.

Years 2-4: The cost of professional monitoring will be the same for subsequent years.

\section{(3) Laos}

Currency: LAK 1,000 = USD 0.125 (April 2012).

\section{Community monitoring}

Training and supervision:

Travel: Travel from Vientiane cost USD 1,688 for 3 trainers.

Accommodation, food and wages: USD 1,256 was paid as a combined per diem to trainers to cover food, accommodation and salaries.

Years 2-4: Refresher training is needed for year 2 but the number of trainers can be reduced to two. The cost of training and supervision will consequently reduce by $33 \%$. Equipment will come to around USD 10 per year.

Implementation (by community members):

Food: No additional food was provided.

Equipment: Basic materials for establishing plots and measuring trees were bought for USD 211.

Wages for community members: Each villager in Sakok was paid USD 5.47 per day when involved in community monitoring and training. Up to twelve villagers participated in the community monitoring and, in total, USD 526 was paid.

\section{Professional monitoring}

Travel and accommodation: Travel was USD 1,688 and accommodation was USD 575.

Food: Food was paid for by the professional monitors out of their salaries.

Equipment: USD 288 was spent on equipment for professional monitors.

Wages: USD 750 was paid in wages to the professional monitors. 
Years 2-4: It is estimated that the cost of accommodation and wages for professional monitoring will be $25 \%$ lower in subsequent years since fewer person-days will be needed. Transport costs will remain the same (USD 1,688).

Equipment will be approx. USD 10 per year.

\section{(4) Vietnam}

Currency VND 10,000 = USD 0.476 (April 2012).

\section{Community monitoring}

$\underline{\text { Diem village }}$

Training and supervision:

Travel: USD 778 was paid to cover the trainers' travel costs.

Accommodation: USD 179 was paid for the trainers' accommodation.

Food: USD 858 was paid in per diems and food for the trainers.

Wages: USD 383 was paid as salary for the trainers.

Years 2-4: Less training will be needed in subsequent years. The cost of training will therefore reduce. It is estimated at one-third of the first year's cost for each of the following years. Equipment will come to around USD 10 per year.

Implementation (by community members):

Food: The villagers received training for 10 days. They were paid USD 58 in per diems and for other minor expenses. Equipment: USD 95 was paid for equipment.

Wages: Villagers in Diem were paid USD 4.76 (VND 100,000) per day when involved in community monitoring. They worked for 21 person-days on community monitoring and were paid USD 100.

Years 2-4: The cost of implementation is estimated as being similar for subsequent years. Equipment will come to around USD 10 per year.

Moi village

Training and supervision:

Travel and accommodation: USD 760 was spent on travel and accommodation for the trainers.

Food: USD 923 was paid for per diems and food for the trainers.

Wages: USD 415 was paid as salaries for the trainers.

Years 2-4: Less training will be needed in subsequent years. The cost of training will therefore reduce. The cost of training is estimated two-thirds of the first year's cost for each of the following years. Equipment will come to around USD 10 per year.

Implementation (by community members):

Food: Villagers were paid USD 255 in per diems.

Equipment: USD 181 was paid for equipment.

Wages: Villagers were paid USD 4.76 (VND 100,000) per day when involved in community monitoring. They worked for 72 person-days on community monitoring and were paid USD 343.

\section{Professional monitoring}

$\underline{\text { Diem village }}$

Travel and accommodation: USD 475 was spent on travel and accommodation for the professional monitors. Food: USD 554 was spent on food.

Equipment: USD 11 was spent on equipment for the professional monitors. Other equipment was borrowed. Wages: USD 255 was paid in salaries for the professional monitors.

Years 2-4: The cost of professional monitoring will be the same for subsequent years.

Moi village

Travel and accommodation: USD 950 was spent on travel and accommodation for the professional monitors. Food: USD 1,152 went on covering the costs of food for the professional monitors. 
Equipment: USD 11 was spent on equipment for the professional monitors. Other equipment was borrowed. Wages: USD 510 was paid in salaries for the professional monitors.

Years 2-4: The cost of professional monitoring will be the same for subsequent years. 
Appendix 4. Comparison of number of trees recorded per $\mathrm{cm}$ interval of tree circumference by community members (white) and professional foresters (grey) in lowland dipterocarp forest in Batu Majang, Indonesia (a), mountain rainforest in Manlin, China (b-c), evergreen monsoon forest in Sakok, Laos (d-e), and Diem (f) and Moi $(\mathrm{g}-\mathrm{i})$, Vietnam $(\mathrm{n}=289$ permanent plots).
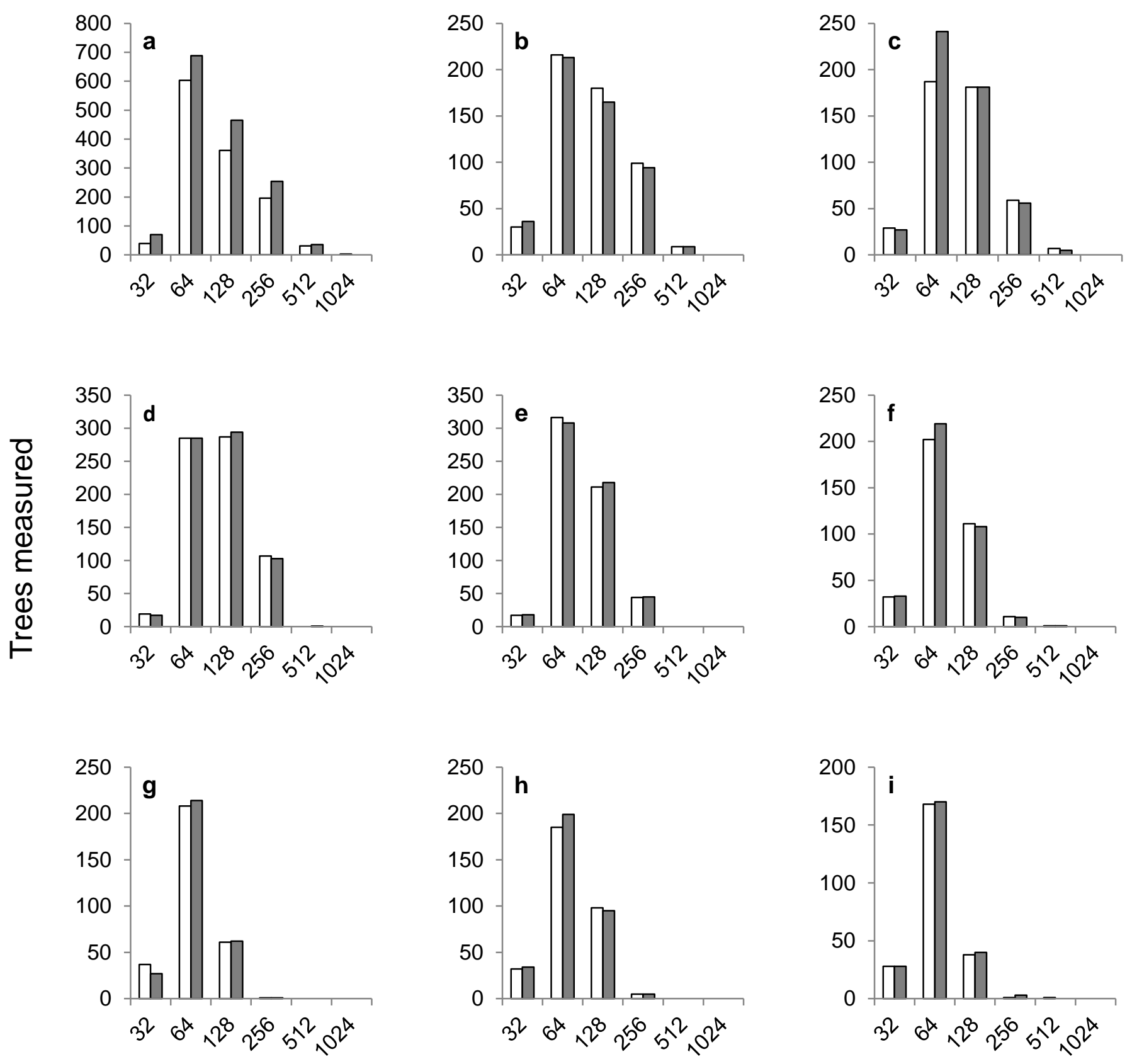

Tree girth $(\mathrm{cm})$ 
APPENDIX 5. Differences in girth measurements by community members and professional foresters based on comparison of individual trees in those sites where trees were individually marked.

\begin{tabular}{lcccc}
\hline Country, area & Girth mean $^{\dagger}$ & S.D. & Skewness & Kurtosis \\
(site number) & $(\mathbf{c m})$ & & & \\
\hline Laos, Sakok (d-e) & $-0,59$ & 2.1 & -3.0 & 9.2 \\
Vietnam, Diem (f) & -0.03 & 1.6 & -3.6 & 15.4 \\
Vietnam, Moi (g-i) & -0.14 & 1.5 & -3.1 & 12.1 \\
\hline
\end{tabular}

${ }^{\dagger}$ The mean difference between community tree girth measurements and forester girth measurements. Negative values indicate a higher measurement among professional foresters. 
APPENDIX 6. Involvement of local stakeholders in monitoring forest biomass (black), biodiversity (shaded), and livelihoods (white) in Climate, Community and Biodiversity Alliance-validated forest carbon projects on each continent $(n=$ 50 forest carbon schemes). The units of the $y$ and $x$-axes are the same as in Fig. 4. The degree of involvement of local stakeholders increases from left to right in each graph. There were no projects in Europe or the Middle East.

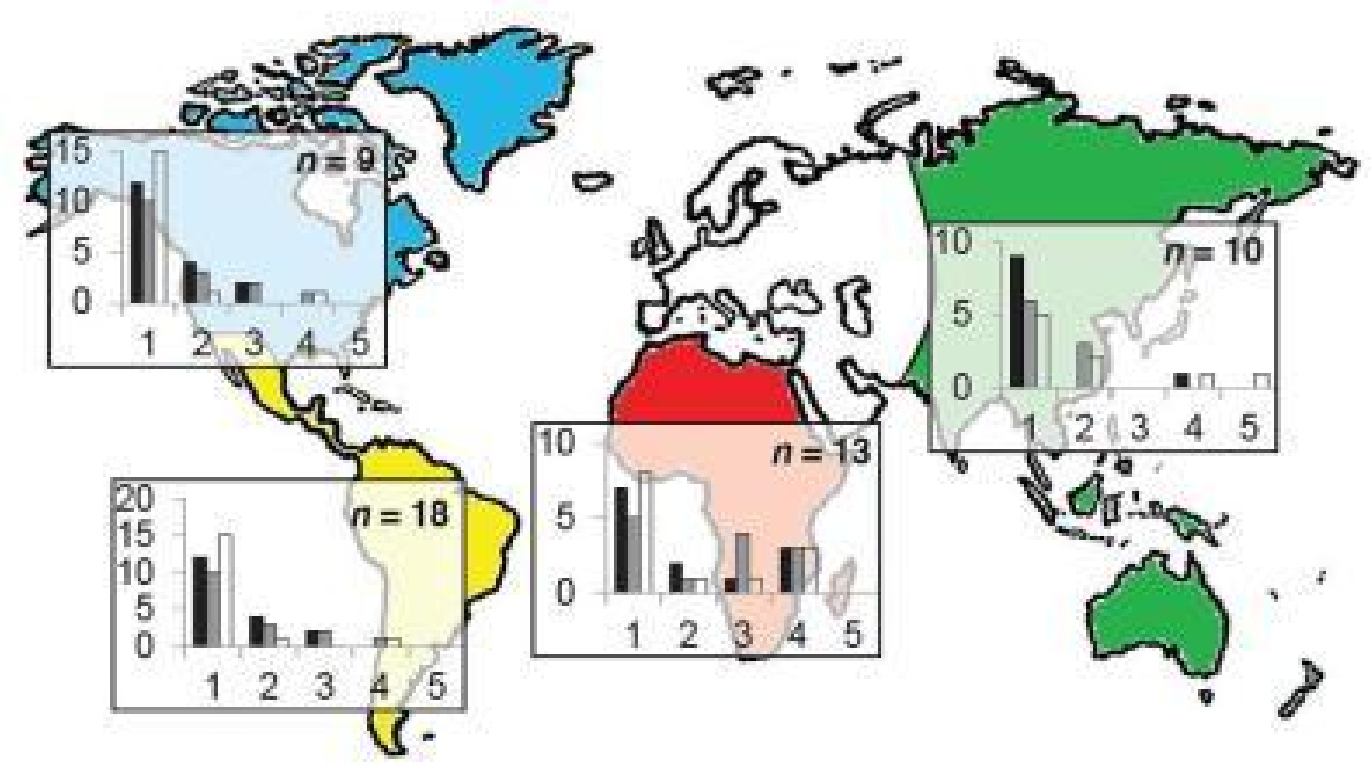


Ecology and Society 18(3): 41

http://www.ecologyandsociety.org/vol18/iss3/art41/

Appendix 7. Appendix 7. Dataset of forest carbon projects validated by the Climate, Community and Biodiversity Alliance.

Please click here to download file 'appendix7.xlsx'. 